\title{
Serum and Glucocorticoid-Inducible Kinase 1 (SGK1) in NSCLC Therapy
}

\author{
Ilaria Guerriero ${ }^{1}$, Gianni Monaco ${ }^{1}$, Vincenzo Coppola ${ }^{2,3, *}$ and Arturo Orlacchio ${ }^{2,3, *}$ (D) \\ 1 Biogem Institute for Genetic Research Gaetano Salvatore, Ariano Irpino, 83031 Avellino, Italy; \\ ilaria.guerriero@biogem.it (I.G.); mongianni1@gmail.com (G.M.) \\ 2 Department of Cancer Biology and Genetics, College of Medicine, The Ohio State University, \\ Columbus, $\mathrm{OH} 43210$, USA \\ 3 Arthur G. James Comprehensive Cancer Center, The Ohio State University, Columbus, OH 43210, USA \\ * Correspondence: vincenzo.coppola@osumc.edu (V.C.); arturo.orlacchio@osumc.edu (A.O.); \\ Tel.: +1-614-688-8038 (V.C.); +1-646-552-0641 (A.O.)
}

Received: 30 October 2020; Accepted: 20 November 2020; Published: 22 November 2020

\begin{abstract}
Non-small cell lung cancer (NSCLC) remains the most prevalent and one of the deadliest cancers worldwide. Despite recent success, there is still an urgent need for new therapeutic strategies. It is also becoming increasingly evident that combinatorial approaches are more effective than single modality treatments. This review proposes that the serum and glucocorticoid-inducible kinase 1 (SGK1) may represent an attractive target for therapy of NSCLC. Although ubiquitously expressed, SGK1 deletion in mice causes only mild defects of ion physiology. The frequent overexpression of SGK1 in tumors is likely stress-induced and provides a therapeutic window to spare normal tissues. SGK1 appears to promote oncogenic signaling aimed at preserving the survival and fitness of cancer cells. Most importantly, recent investigations have revealed the ability of SGK1 to skew immune-cell differentiation toward pro-tumorigenic phenotypes. Future studies are needed to fully evaluate the potential of SGK1 as a therapeutic target in combinatorial treatments of NSCLC. However, based on what is currently known, SGK1 inactivation can result in anti-oncogenic effects both on tumor cells and on the immune microenvironment. A first generation of small molecules to inactivate SGK1 has already been already produced.
\end{abstract}

Keywords: NSCLC; SGK1; chemotherapy; immunotherapy

\section{Introduction}

Lung cancer was the most commonly diagnosed cancer worldwide in 2018, accounting for $11.6 \%$ of new total cancer cases (14.5\% in males and $8.4 \%$ in females) and causing about 1,700,000 deaths (18.4\% of all cancer-related deaths) [1]. Based on its histopathological features, lung cancer has been categorized into small-cell lung carcinoma (SCLC), which represents $15 \%$ of all lung cancer cases, and non-SCLC (NSCLC), which accounts for the remaining 85\%. NSCLC is further classified into three subgroups: adenocarcinoma (LUAD), squamous cell carcinoma (LUSC), and large-cell carcinoma (LACC) [2]. Finally, these different types of NSCLC subgroups have been classified according to the WHO guidelines, which were revised in 2015 [3]. In detail, LUAD can be divided in three prognostic groups: lepidic pattern (good prognosis), acinar and papillary pattern (intermediate prognosis), and micropapillary and solid pattern (worse prognosis) [4]. LUSC, instead, can be categorized in three histological groups: keratinizing, non-keratinizing, and basaloid form, according to the correlation between keratinization and clinical outcome [5]. 
LACC has neither clear features of LUAD and LUSC nor expression of neuroendocrine markers. Generally, LACC tumors are considerably undifferentiated and included in this group because of exclusion from the previous ones [6].

All NSCLCs are generally characterized by cellular subpopulations with distinctive molecular and histological features that require a "personalized medicine" type of treatment. Despite significant improvement due to the introduction, in the clinics, of novel treatments with small molecules inhibiting tyrosine kinases and immunotherapy, NSCLC remains a deadly disease, especially when invasion and metastases develop [7]. The unmet medical need for curative therapeutic alternatives can be overcome only by a deeper understanding of the unknown mechanisms underlying tumor progression, including the relationship between cancer cells and the tumor microenvironment.

In recent decades, a number of genetic alterations and oncogenic driver mutations have been identified in NSCLC, thus emphasizing the heterogeneous nature of this disease [8]. In this regard, phosphoinositide 3-kinase (PI3K) is the most deregulated pathway in cancer, with a broad pathological impact $[9,10]$. Although protein kinase B (AKT) is classically considered the main effector of the PI3K signaling cascade, recent growing evidence is suggesting that other proteins impinging upon this pathway or intersecting with it are playing a critical role during neoplastic transformation independently of AKT [11]. These players are also involved in the establishment of resistance to PI3K/AKT inhibitors $[12,13]$ and several of them have become targets of therapy. Targeted drugs against epidermal growth factor receptor (EGFR), anaplastic lymphoma kinase (ALK), ROS proto-oncogene 1 (ROS1), Ki-ras2 Kirsten rat sarcoma viral oncogene homolog (KRAS), B-Raf Proto-Oncogene (BRAF), human epidermal growth factor receptor 2 (HER2), rearranged during transfection (RET), and MET, are now successfully used in clinics [14-18]. Several of these compounds have distinctly improved the outcome of NSCLC treatment [19].

There are a variety of genetic and epigenetic alterations that can negatively impact the efficacy of a treatment regimen. They can affect the primary target of the drug or other proteins, which can activate pathways parallel or downstream in respect to the original target, thus overcoming its direct inhibition [20-25].

Serum and glucocorticoid-inducible kinase 1 (SGK1) is a member of the AGC kinase family of serine/threonine kinases. Some of the most notable members of this family are AKT, 3-phosphoinositidedependent kinase-1 (PDK1), Ribosomal 66 kinase p70 (S6K), Protein Kinase C (PKC), and ribosomal s6 kinase p90 (RSK). Studies that aimed to elucidate the biological functions and the specific targets of phosphorylation of each AGC kinase have been hampered by the high degree of sequence and structural homology observed in this family. Indeed, SGK1 and AKT do share a large homologous sequence and several targets [26,27]; however, differently from AKT, SGK1 does not possess a pleckstrin homology $(\mathrm{PH})$ domain and, therefore, it cannot directly interact with phosphatidylinositol 3, 4, 5 tris-phosphate [28].

SGK1 is activated by a two-step process. First, a phosphorylation on Ser422 performed by the mammalian target of rapamycin complex 2 (mTORC2) induces the kinase to assume an open conformation. Full activation is achieved through a second phosphorylation event operated by PDK1 on SGK1 Thr256. Specifically, PDK1 PIF pocket is responsible to recognize SGK1 after it has been primed by mTORC2 $[29,30]$. This is another important difference with AKT, which does not require PDK1 PIF pocket to be activated [31].

Among the physiological processes regulated by SGK1 are ion transport, embryo implantation and pregnancy, T-cell activation, macrophage motility and function, insulin sensitivity, and apoptosis [32-38]. It is, then, no surprise that SGK1 has been implicated in a variety of diseases [39-41], including in different types of human cancer [42-44].

This review focuses on the potential targetability of SGK1 in NSCLC specifically. It is beyond our scope to systematically list of all the potential or verified targets of SGK1 phosphorylation. On the other hand, we aim to highlight pro-tumorigenic signaling networks and biological processes that the activation of SGK1 mediates directly or indirectly in NSCLC tumors. Of particular interest are the 
effects that SGK1 activation has in cells of the immune system to promote their differentiation toward pro-tumorigenic subpopulations.

\section{The SGK Protein Family}

The SGK family consists of three different SGK paralogs: SGK1, SGK2, and SGK3 [45]. They are encoded by three distinct genes, each one localized on a different chromosome [46].

SGK1, SGK2, and SGK3 proteins share a highly homologous structural organization, containing an $\mathrm{N}$-terminal variable domain, a catalytic domain, and a hydrophobic domain at the $\mathrm{C}$-terminal (Figure 1).

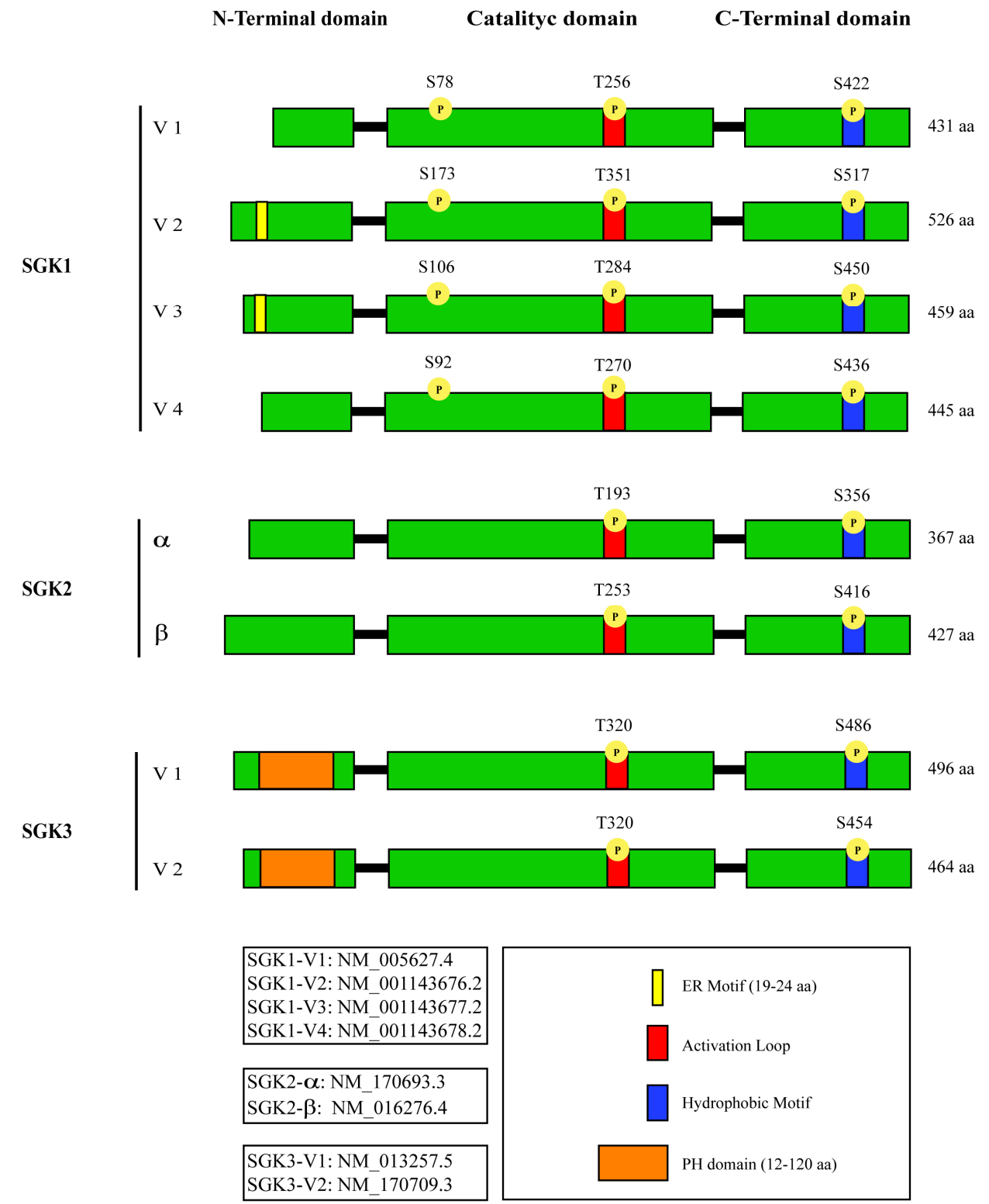

Figure 1. Schematic representation of known serum and glucocorticoid-inducible kinases SGK1, SGK2, and SGK3 splicing variants.

The three paralogs show the lowest degree of homology at the N-terminal domain [47,48].

SGK3 is the only family member with a pleckstrin homology (PH) domain at the N-terminus, which is important for its membrane localization $[33,49]$. SGK2 has a shorter N-terminus and is 
expressed only in liver, pancreas, kidney, and, at lower levels, in brain [47]. SGK1 and SGK3 are ubiquitously expressed [48].

Each SGK paralog has more than one splicing isoform. However, the current knowledge about the functional relevance of each one of those variants is still limited.

Four isoforms of SGK1 have been described. They all differ at the N-terminal domain due to alternative use of different translation initiation sites [50]. As a functional consequence, SGK1.2 and SGK1.3 are rapidly degraded through the $26 \mathrm{~S}$ proteasome because of a hydrophobic motif at the $\mathrm{N}$-terminal domain, which is missing in the other two variants [50]. This motif is responsible for the localization of SGK1 at the endoplasmic reticulum (ER) [51], where it can be ubiquitinated by the stress-associated chaperone-dependent E3 ligase (CHIP) [52]. The SGK1.1 isoform is not only less susceptible to ubiquitination by lacking the $\mathrm{N}$-terminal ER-homing motif but also highly expressed in brain and pancreas. Furthermore, like SGK2 and SGK3, SGK1.1 is not sensitive to glucocorticoid stimulation [53]. Another important characteristic of this isoform is the cellular localization. In fact, SGK1.1 can bind phosphatidylinositol 4,5-bisphosphate though a cluster of positively charged and hydrophobic residues [54,55]. When levels of phosphatidylinositol 4,5-bisphosphate drop, SGK1.1 moves to the cytosol and accumulates in the nucleus thanks to the same aminoacidic cluster which is also a nuclear localization signal $[54,55]$.

Both SGK2 and SGK3 have two variants, SGK2 $\alpha$ and SGK2 $\beta$, which differ at the N-terminus, while the SGK3.1 and SGK3.2 isoforms are the result of an alternative exon exclusion event.

Like with SGK1.4, the functional relevance of SGK2 and SGK3 isoforms is still unknown. However, the existence of three SGK genes and multiple variants is a confounding factor in the identification of targets and functions specific to SGK1.

\section{Mouse Models to Elucidate SGK Protein Functions}

Mouse models have provided critical evidence in establishing what the effects of SGK protein depletion are in vivo.

Interestingly, despite its ubiquitous expression, the genetic inactivation of SGK1 in mouse causes only mild phenotypes related to ion physiology. In fact, SGK1 knockout mice are viable but show a decreased ability to retain salt when exposed to a salt-deficient diet [56], an altered renal response to $\mathrm{K}^{+}$ load [57], and a decreased renal ability to excrete $\mathrm{Ca}^{2+}$ [58]. Salt depletion may also explain why those mice show increased plasmatic aldosterone concentrations [57]. Further, SGK1 ${ }^{-/}$mice exposed to either a high-fructose or high-fat diet show resistance to hypertension $[59,60]$ and are less responsive to the effect of mineralocorticoids on both salt appetite [61] and intestinal glucose uptake [62]. The latter is also reduced in brain cells, adipocytes, and skeletal muscle [63]. Finally, SGK1 ${ }^{-/-}$mice show a mild defect of platelet migration [64].

The deletion of SGK3 in mouse does not cause a strong phenotype either. SGK3 ${ }^{-1-}$ mice may have a transient delay both in hair growth and body weight increase [65]. Only a more detailed analysis revealed that SGK3 deletion results in reduced intestinal glucose transport and a very mild locomotion defect [66].

Interestingly, SGK1/SGK3 double-knockout mice show a compound phenotype that combines those observed in the two single mutants [67].

SGK2 ${ }^{-/}$mice do not show any phenotype. However, the analysis of mice lacking both SGK1 and SGK2 has revealed that SGK2 bears a certain degree of functional redundancy with SGK1 in contributing to water and electrolyte homeostasis during salt deprivation [68].

In summary, the engineering of different SGK-deficient animals has shown that there are biological and cell-type functions specific to SGK1 that neither AKT nor SGK2 and SGK3 are able to compensate for [69]. On the other hand, these in vivo observations have also suggested that inhibition of SGK1 could be safely achieved. 


\section{SGK1 Expression}

SGK1 expression is proven to be tightly regulated both transcriptionally and posttranscriptionally $[32,33,70,71]$.

SGK1 is ubiquitously expressed and it is the only family member that was reported being regulated by glucocorticoids [47]. Growth factors, cytokines, and insulin are among the diverse types of stimuli that can affect SGK1 expression $[42,72,73]$ (Table 1 ).

SGK1 is functionally connected to cellular stress and, unlike the other two paralogs, can be phosphorylated on S78 by BIM-K1 [74] and p38-MAPKinase [75]. Different types of cellular stress have effects on SGK1 expression, including DNA damage and heart ischemia [76,77] (Table 1).

Table 1. Known regulators of SGK1 expression and activity. Abbreviation: Interleukin-2 (IL-2), Internleukin-6, tumor necrosis factor alpha (TNF- $\alpha$ ), Fibroblast growth factor (FGF), Transforming growth factor beta (TGF- $\beta$ ), Platelet-derived growth factor (PDGF), Follicle-stimulating hormone (FSH), Luteinizing hormone (LH), Insulin-like growth factor 1 (IGF1).

\begin{tabular}{ccc}
\hline Type of Stimuli & Regulators of SGK1 & References \\
\hline \multirow{4}{*}{ Cytokines } & IL-2 & {$[78]$} \\
& IL-6 & {$[75]$} \\
& Colony-Stimulating Factor 2 & {$[79]$} \\
& TNF- $\alpha$ & {$[79]$} \\
\hline & Glucocorticoids & {$[70]$} \\
& Mineralocorticoids & {$[80]$} \\
Growth Factors & FGF & {$[72]$} \\
& Serum & {$[70]$} \\
& TGF- $\beta$ & {$[81]$} \\
& PDGF & {$[72]$} \\
& FSH & {$[82]$} \\
& LH & {$[83]$} \\
& Insulin & {$[84]$} \\
& IGF1 & {$[26]$} \\
\hline & Osmotic stress & {$[85]$} \\
& Heat-shock & {$[86]$} \\
Cellular stress & UV & {$[86]$} \\
& Ischemic injury & {$[87]$} \\
& Hepatitis & {$[88]$} \\
& Sorbitol & {$[89]$} \\
& Hydrogen peroxide & {$[47]$} \\
& Neuronal injury & {$[87]$} \\
High Glucose & {$[90]$} \\
\hline
\end{tabular}

Interestingly, transcript levels do not always correlate with amount of protein. In fact, some tissues show high expression of SGK1 when probed for mRNA but a low protein amount. Other than artifacts in the methods used for detection of SGK1 mRNA and protein, this is also, in part, attributed to the short half-life of the kinase active form $(\sim 30 \mathrm{~min})$ [91].

Based on two independent studies that assessed a possible interaction by surface plasmon resonance (SPR), it has been suggested that the ubiquitin ligase Nedd4-2 targets SGK1 for degradation by the $26 \mathrm{~S}$ proteasome $[92,93]$. This hypothesis is supported by the observation in HEK-293T and COS-7 cells that Nedd4-2 overexpression leads to decreased SGK1 levels while Nedd4-2 silencing results in the increase in the SGK1 half-life [91,94,95]. On the other hand, SGK1 ubiquitination and subsequent degradation are also promoted by a Rictor/Cullin E3 ligase complex [96,97]. Interestingly, AGC kinases such as SGK1, AKT, and S6K can phosphorylate Rictor on T1135. This phosphorylation is reported to impair the interaction between Rictor and Cullin-1, resulting in the inhibition of SGK1 ubiquitination and degradation and establishing a positive feedback signaling loop [96,97]. 
The glucocorticoid-induced leucine zipper protein-1 (GILZ1) [98] is reported to stabilize SGK1 by opposing its localization to the ER and, therefore, limiting its interaction with ER-based E3 ubiquitin ligases, such as CHIP [52] and Synoviolin 1 (HRD1) [91].

\section{SGK1 Is a Predicted Target of microRNAs Relevant in NSCLC}

MicroRNAs (miRNAs) are an integral part of the complex mechanisms tightly regulating SGK1 expression at the post-transcriptional level. They are deregulated in cancer and generally exert oncogenic effects through the silencing of their target genes. NSCLC patients frequently show altered expression of several miRNAs that have been associated with the progression of disease and resistance to therapy [99-103]. Several of those miRNAs that are known to be deregulated in lung cancer are also predicted to target SGK1 [104].

For a group of miRNAs that are downregulated in NSCLC, the literature is quite consistent.

miR-497 is down-regulated in several human malignancies, suggesting a tumor-suppressive role [105]. In NSCLC cell lines and patient specimens, miR-497 has been found downregulated and has been reported to inhibit cell proliferation in vitro and tumor growth in vivo by targeting the hepatoma-derived growth factor (HDGF) [106]. Moreover, miR-497 is able to function as a tumor-suppressor miRNA in NSCLC by targeting the vascular endothelial growth factor A (VEGF-A) [107], cyclin E1 [108] and the Yes-associated protein 1 (YAP1) [109,110]. Due to the complicated interaction with its many downstream targets, miR-497 is currently being studied more as a diagnostic marker rather than a therapeutic target [105]. However, it is interesting to note that this miRNA has also been reported to target AKT2, impairing tumor growth and chemoresistance in lung cancer cell lines and xenograft models [111]. If its ability to target SGK1 will be experimentally validated, this miRNA could be a tool to inhibit both kinases at the same time.

miR-15 was identified for the first time in 2002, together with miR-16, as a potential oncomiR in the pathogenesis of chronic lymphocytic leukemia (CLL), being frequently deleted and/or downregulated in this malignancy [112]. Recently, Yang et al. performed a meta-analysis to assess the prognostic value of miR-15a in human cancers [113], confirming that this miRNA is frequently downregulated, in particular in NSCLC [114]. Moreover, miR-15a has been found to regulate epithelial-to-mesenchymal transition (EMT) by silencing Twist1 [115], a key regulator of this process, together with Slug, which has a relevant role in lung carcinogenesis [116]. Interestingly, miR-15a has been proposed as a prognostic biomarker in NSCLC since is able to reduce the expression of several oncogenic proteins [117]. Furthermore, decreased levels of miR-15a have been associated to cisplatin resistance in NSCLC [118]. The induced overexpression of this miRNA is able to turn back on apoptosis and autophagy in cancer cells treated with cisplatin, possibly by targeting Bcl-2 [119]. SGK1 has been shown to play a role in this process, since its inhibition, by either GSK650394 or SGK1 shRNA, may induce G2/M arrest, apoptosis, and autophagy through the mTOR-FoxO3a pathway in other human cancers $[120,121]$.

$\mathrm{miR}-181 \mathrm{a} / \mathrm{b}$. In recent years, different groups have proposed the use of miR-181a/b in new therapeutic approaches to treat NSCLC [122]. Indeed, miR-181b has been found increased in stage I NSCLC while its expression is significantly reduced at later stages [123-128]. miR-181b overexpression inhibits tumor cell proliferation, migration, invasion, and metastatic colonization. Therefore, the progressive down-regulation of this miRNA is a powerful way to increase cancer aggressiveness. Interestingly, miR-181a plays a role in the function of tumor-associated macrophages, showing higher expression in the M2 immunosuppressive phenotype compared to M1 [129]. Since the immune contribution is crucial in the tumor microenvironment to sustain the progression of the disease, and taking into account that the M2 macrophages localize in the hypoxic regions of lung tumors, miR-181a could have a critical role through specific targets, such as SGK1, which is reported to be involved in the regulation of macrophage polarization $[130,131]$ and is also activated by hypoxic stimuli $[130,132,133]$.

miR-125. miR-125a and 125b share a seed sequence and possibly the same targets. miR-125a is another one of those miRNAs generally down-regulated in many human cancers, including 
NSCLC [134]. It has been shown to function as a tumor suppressor by targeting signal transducer and activator of transcription 3 (STAT3) [135] and several other downstream effectors of the KRAS and nuclear factor-kappa B (NF-kB) pathways, often together with miR-23b [136]. Both miR-125a and miR-125b are involved inflammatory processes. Their delivery by bone marrow mesenchymal stem cell-derived exosomes ameliorates the symptoms of colitis in mice through the silencing of STAT3. At the same time, they have been shown to inhibit Th17 cell differentiation while favoring regulatory $\mathrm{T}$ cell (Treg) expansion [137]. Interestingly, SGK1, which is predicted to be targeted by miR-125, is similarly involved in Th17 and Treg cells' regulation (see below).

Finally, a group of miRNAs that are predicted to target and downregulate SGK1 [104], such as miR-96 [138-140], miR-183 [141-143], miR-130b [144-146], miR-182 [147-150], miR-301b [151,152], miR-17 [153,154], and miR-9 [155-158], are overexpressed in NSCLC. However, although they have not been validated yet, the fact that SGK1 is frequently upregulated suggests that mechanisms allowing escape from the miRNA-mediated suppressive effect might be in place. On the other hand, these miRNAs target other molecules that directly or indirectly cooperate with SGK1 signaling. Therefore, miRNAs can add an additional layer of complexity to the regulation of SGK1 expression. Future investigations about their interconnection in the context of NSCLC could lead to a better understanding of the pathophysiology of the disease and new theragnostic tools.

\section{SGK1 Is a Prognostic Factor in NSCLC}

SGK1 is frequently upregulated in NSCLC. Both its transcript and protein expression have been related to prognosis [159-162]. In 2012, Abbruzzese et al. found that higher SGK1 mRNA expression in NSCLC patients correlated with worse prognosis, supporting an oncogenic role of SGK1 [160]. The authors also analyzed the expression of each SGK1 splice variant separately. However, such an analysis produced data that were not as statistically significant as when considering the sum of the four variants. High SGK1 mRNA expression was detected in mainly LUSC, but it needs to be noted that the study was not able to find a correlation with prognosis when the protein levels of SGK1 were measured. There may be several possible explanations for this discrepancy. For example, the different half-lives of the four splicing variants and the possible effect of specific miRNAs could result in translational rather than transcriptional regulation. On the other hand, it is also possible that the measurement of protein expression by immunohistochemistry is far less precise than quantitative PCR and, therefore, the cohort of samples $(n=66)$ used for the study may have been underpowered.

A recent study by Pan et al. assessed the expression of SGK1 by immunohistochemical detection using a larger cohort of 150 cases consisting uniquely of human lung adenocarcinoma. In contrast to Abbruzzese et al., the authors found a significant correlation between high SGK1 protein levels and increased nodal invasion and advanced disease (stage III/IV). On the other hand, low levels of SGK1 correlated with the absence of nodal metastasis. No significant correlation of SGK1 levels with age, sex, smoking history, histopathologic grade, or T stage was found [161].

In 2018, Tang et al. also correlated SGK1 protein expression with several clinical parameters of NSCLC patients [162]. The authors reported a significant association between high SGK1 protein expression and differentiation or histological type, but not with lymph node metastasis and advanced TNM staging. More importantly, their analysis showed that high expression of SGK1 was a significant negative prognostic factor for 5-year survival.

Since SGK1 expression is related to cellular stress, it is plausible and, in many cases, demonstrated, that high expression can be found in high-grade/advanced tumors, which are frequently characterized by enhanced metabolism and excessive oxidative stress due to the "Warburg effect" [130,132,133,163]. In addition, external stress stimuli can also produce DNA damage with the consequent activation of P53 that, in turn, can activate the transcription of SGK1 [162] (see below). 


\section{Potential Targeting of SGK1 in Combination with Chemotherapy to Treat NSCLC}

Despite the recent success in the management of NSCLC, there is still an urgent need for innovative treatment strategies and new potential targets. Chemotherapy is still used in most patients. Usually, platinum-based agents (cisplatin or carboplatin) are used in combination with other drugs, such as gemcitabine, vinorelbine, paclitaxel, or taxotere [164]. Finally, corticosteroids are often used as a co-treatment in advanced lung cancer [165].

Resistance to treatment is a major common limitation of the current therapeutic modalities [166]. The display of intrinsic resistance is evident at the initial treatment due to innate tumor features usually of a genetic or epigenetic nature. Most commonly, tumors acquire resistance due to adaptive advantageous adaptation or clone selection [166].

Along the same lines, it is widely accepted that single modalities of treatment are rarely curative, while combinatorial strategies are much more efficacious. Hence, due to the vast signaling network that SGK1 operates, its inactivation can result in synergistic effects together with targeted- and chemotherapy. Theoretically, the elevated levels that SGK1 shows in NSCLC patients provide a window of treatment that may spare normal tissues. This is in addition to the fact that total body inactivation in mice only causes mild phenotypes.

P53 is key in the response to chemotherapy, which generally induces DNA damage. SGK1 has recently been linked with resistance to DNA damage-induced apoptosis in ERCC excision repair 1 (ERCC1)-defective lung cancer cells, suggesting an indirect involvement with specific types of DNA damage [167]. In this regard, SGK1 is known to phosphorylate mouse double minute 2 homolog (MDM2) and, therefore, affect the levels and the regulatory activity on proliferation and cell survival of P53 [168]. In turn, P53 is known to positively regulate the transcription of SGK1, establishing a negative feedback loop between the two molecules [76,169,170]. Moreover, P53 degradation can also be promoted through Nedd4-2, which is an SGK1 target [171]. This observation also suggests that antiapoptotic effects exerted by SGK1 may be delivered through the regulation of P53, at least in some cases.

One pivotal cellular player protecting from apoptosis, including when induced by DNA damage, is the nuclear factor-kappa B (NF- $\mathrm{kB})$. Constitutive NF- $\mathrm{kB}$ activation has been reported in different kinds of tumors [172,173]; more importantly, high levels of NF-KB activation have been found in tumor samples from lung cancer patients, both for SCLC and NSCLC, and it is associated with poor prognosis $[173,174]$. Indeed, NF- $\mathrm{KB}$ inhibition has been shown to negatively affect lung cancer cell survival and proliferation [175-177]. In cancer cells, NF- $\mathrm{kB}$ activation is also known to be induced by chemotherapeutics and radiation, thus contributing to resistance $[178,179]$. On the other side, it has been shown that NF- $\mathrm{kB}$ inhibition can increase the efficacy of both therapeutic approaches in vitro and in vivo $[180,181]$. SGK1 can activate NF- $\mathrm{KB}$ signaling though two different mechanisms. On the one hand, SGK1 phosphorylates the IкB kinase $\beta$ at Ser177 and Ser181, thus promoting its degradation and, consequently, NF- $\mathrm{kB}$ nuclear translocation. On the other hand, SGK1 directly phosphorylates p300 at Ser1834, thus enhancing NF-KB acetylation and activity [182]. Therefore, targeting of SGK1 could constitute an alternative to direct NF-KB inhibition, with the potential advantage of limiting the side effects observed with that approach [178,183-187].

SGK1 seems to be at the crossroad between PI3K and Wingless-related integration site (WNT) signaling. SGK1 has been reported to interact with Parvin Alpha (PARVA), leading to the activation of Integrin Linked Kinase (ILK) with the consequent phosphorylation of AKT and the glycogen synthase kinase $3 \beta$ (GSK3 $\beta$ ) (Ser9) [188]. Interestingly, a recent article has shown that SGK1 depletion leads to impaired growth and migration of NSCLC cells [159]. More importantly, the authors found that SGK1 knockdown leads to a lower level of $\beta$-catenin, confirming that SGK1 can inactivate GSK-3 $\beta$ and cause accumulation of $\beta$-catenin.

This result not only opens new avenues of investigation but also shows how SGK1 promotes one of the major oncogenic pathways, such as the $\mathrm{Wnt} / \beta$-catenin signaling. It has been established that WNT signaling plays a role in drug resistance in NSCLC [189-191]. Indeed, it has been reported 
that activation of the Wnt/ $\beta$-catenin signaling pathway by inhibiting cytoplasmic GSK-3 $\beta$ induces increased resistance to cisplatin in A549 cells [192]. Using the same cell model, Zhang et al. reported that knockdown by small interfering RNA (siRNA) of $\beta$-catenin increases sensitivity to cisplatin by decreasing both mRNA and protein levels of the antiapoptotic factor B-cell lymphoma-extra large (Bcl-xl) [193]. However, Wnt/ $\beta$-catenin signaling is now recognized as a major determinant of the "immune exclusion" phenotype of lung tumors by decreasing the infiltration of immune system killer cells and reducing the efficacy of immune checkpoint inhibitor (ICI)-based therapy [194,195].

In a perspective of cancer treatment, an interesting area of investigation in relation to the potential therapeutic effects provided by targeting of SGK1 is offered by the control exerted by this kinase on a variety of channels involved in ion and nutrient absorption [196]. The mild phenotypes observed in SGK KO mouse models are in line with these channel-related functions. Most importantly, several of those channels have independently been proposed, themselves, as candidate targets of therapy in lung cancer.

The chemical and genetic inactivation of Kv1.3 resulted in a significant reduction in proliferation in A549 cells both in vivo and in vitro [197]. Overexpression in the same cell line of the acid-sensing ion channel 1 (ASIC1) promotes proliferation and migration induced by extracellular acidosis. On the other hand, chemical and genetic inhibition of ASIC1 reduced proliferation and migration of A549 cells [198].

Other SGK1-controlled targets are the $\mathrm{Ca}^{2+}$ release-activated $\mathrm{Ca}^{2+}$ channels (ICRAC). They are composed of the ORAI1, -2 , and -3 subunits, which form the actual pore, and the regulatory elements stromal interaction molecule (STIM) -1 and -2. SGK1 both negatively affects ORAI1 degradation by repressing the ubiquitin ligase Nedd4-2 and increases the transcription of ORAI1 and STIM1 through NF-kB $[196,199]$. Recent reports show that ORAI1 is associated with poor prognosis in NSCLC and its knockdown negatively affects PI3K/AKT/ERK signaling [200].

From a therapeutic point of view, STIM1 knockdown has been shown to inhibit proliferation both in vivo and in vitro in NSCLC cell lines [201]; however, there are contrasting reports on its effect on cisplatin-induced apoptosis [202,203].

Finally, another SGK1 target, the epithelial sodium channel (ENaC), and specifically its alpha subunit, is a direct transcriptional target of the oncogene achaete-scute homolog 1 (ASCL1) in lung neuroendocrine tumors [204].

\section{Potential Targeting of SGK1 in Combination with Immune-Therapy to Treat NSCLC}

Tumor development is the result of a tug-of-war between cancer cells and the surveillance exerted by the immune system. Reactivation and boosting of the immune system anticancer response using checkpoint inhibitors (ICIs) against the programmed cell death protein 1 (PD1), the programmed death-ligand 1 (PD-L1), and the cytotoxic T-lymphocyte-associated protein 4 (CTLA4) have now set new standards for treatment of NSCLC, especially in cases without an identified driver mutation [205]. Patient response to those drugs can be dramatic, with spectacular results at times. However, about half of the cases do not respond to ICIs to begin with and most responses are only temporary. Due to the fact that SGK1 has been associated with drug resistance in several types of cancer [206], targeting of SGK1 in combination with ICIs can provide a potential synergy because of both tumor cell-intrinsic and -extrinsic effects.

Corticosteroids are used in advanced NSLC to mitigate the inflammation associated with the tumors [165]. However, these drugs can exert a global tumor-promoting effect because of tumor cell-intrinsic and tumor cell-extrinsic actions.

Specific to NSCLC, exposure to dexamethasone of adenocarcinoma cell lines induces inhibition of apoptosis by upregulation of SGK1 [207]. Since SGK1 is downstream of the PI3K-AKT signaling axis, its glucocorticoid-induced upregulation could explain the appearance of resistance to PI3K-AKT by "opportunistic compensation" [13]. 
Mechanistically, it is not yet understood how SGK1 exerts its oncogenic role. However, it has been proposed that SGK1 might, at least in part, promote cancer proliferation, differentiation, migration, invasion, and resistance to alkylating chemotherapy through the activation of its best characterized downstream target, N-myc downstream regulated gene 1 (NDRG1) [208,209]. In NSCLC, the chromosomal region including NDRG1 is consistently amplified and the gene over-expressed [210] SGK1 can promote stem-like properties of lung cancer cells by preventing c-Myc degradation through ubiquitination operated by the S-phase kinase-associated protein 2 (Skp2). NDRG1 inactivates cyclin-dependent kinase 2 (CDK2), leading to reduced Skp2 phosphorylation [208]. Moreover, the levels of expression of NDRG1 in NSCLC patients are associated with poor prognosis and advanced T-stage [211,212].

SGK1 is also responsible of the inhibitory phosphorylation of the forkhead transcription factor FKHRL1 (also known as FoxO3a), thus inducing cell survival and cell cycle progression [169]. In NSCLC patients, FoxO3a expression has been observed to be significantly decreased in tumor tissues compared $[213,214]$ with adjacent normal tissues. Evidence suggests that FoxO3a inhibits the expression of EGFR pathway substrate 8 (EPS8), preventing cancer progression [213]. Furthermore, FoxO3a is frequently deleted in early-stage lung adenocarcinoma and reported to stimulate apoptosis in response to DNA-damaging agents in adenocarcinoma cell lines [215].

All considered, the targeting of SGK1 could potentially eliminate tumor cell-intrinsic pro-tumorigenic effects by ablating its corticosteroid-induced upregulation and signaling.

Targeting of SGK1 has the potential to affect the anti-tumor immune response significantly and positively through other mechanisms too.

As mentioned above, SGK1 knockdown in tumor cells can lead to lower levels of $\beta$-catenin. WNT/beta catenin signaling is now accepted to be one major factor in determining an "immune-exclusion" phenotype where lymphocytes are kept out of tumor masses [194,195]. Therefore, SGK1 targeting can be beneficial in combating immune exclusion.

Targeting of SGK1 is also predicted to affect immune system cells directly. In addition to the aforementioned potential role in promoting macrophage differentiation towards the M2 pro-tumorigenic phenotype, GSK1 may also promote T-cell differentiation toward tumor-promoting subpopulations. Indeed, for an effective immune response, the balance between specific types of T-cells, such as that of T-helper1 and T-helper2 (Th1/Th2) or that of Th17 and regulatory T cells (Treg), has been shown to be critical. The Th1/Th2 ratio is being extensively studied not only in NSCLC microenvironment but in other cancers as well [216-221].

Th1 cells produce interleukin (IL)-2, interferon-gamma (IFN- $\gamma$ ), and tumor necrosis factor-alpha (TNF- $\alpha$ ), and seem to be the main effectors of host immune response against intracellular pathogens. Th2 cells, on the other hand, produce IL-4, IL-5, IL-6, IL-10, and IL-13, and are involved in allergic responses and protection against certain parasitic infections [222,223].

By phosphorylating GSK3 $\beta$ and Nedd4-2, SGK1 can skew the differentiation of Th1/Th2 cells.

In 2014, Heikamp et al. demonstrated that SGK1 is essential for the differentiation of CD4 ${ }^{+} \mathrm{T}$ cells into Th2 helper cells [35]. Specifically, SGK1 phosphorylation of Nedd4-2 inhibits JunB ubiquitination, therefore stabilizing it. This, in turn, activates a gene expression pattern involving IL-4 and GATA-3, which favors the differentiation in Th2 cells. At the same time, by inhibiting GSK3 $\beta$ and stabilizing $\beta$-catenin, SGK1 induces the expression of T cell factor 1 (TCF1), which represses the transcription of genes associated with the Th1 phenotype, such as INF- $\gamma$. The same authors also reported that mice lacking SGK1 specifically in CD4 ${ }^{+}$helper precursor cells showed decreased IL-4 and increased levels of IFN- $\gamma$ and were able to mount an effective immune response to B16 melanoma cells in comparison to wild-type controls. This is in line with the role of IFN- $\gamma$ in affecting the activity of natural killer cells, macrophage activation, and antigen presentation and promoting cancer cell elimination by engaging tumor-specific CD8 ${ }^{+}$cytotoxic T lymphocytes [219,224]. 
It is worth noting that GILZ, which is known to stabilize SGK1, when overexpressed in CD4 ${ }^{+}$cells, can have opposite effects when compared to SGK1 deletion. In fact, GILZ transgenic mice showed an increase in IL- 4 and a decrease in IFN- $\gamma$ levels [225].

Targeting of SGK1 can also alter the balance between Th17 and Treg cells, which has also been found to be important, specifically in NSCLC [226-228]. SGK1 favors the Th17 lineage by increasing IL-23 signaling though inhibitory phosphorylation of FoxO1, ultimately relieving its repressing activity on IL-23 receptor expression $[229,230]$. FoxO1 can also affect Treg by controlling the expression of Foxp3 [231]. Th17 and Treg cells are generally thought to play opposing roles in regulating immunity [232]; however, while their balance is critical for maintaining homeostasis, their functions have been shown to be context-dependent, allowing them to play dual roles in cancer, and specifically in NSCLC [233-235].

Ultimately, more studies are necessary to both elucidate the role of SGK1 as a regulator of immune cell differentiation and to investigate its potential as target to improve cancer immunotherapy. Immunocompetent mouse models should be used for this aim.

\section{SGK1 Inhibitors}

The search for molecules inactivating SGK1 has already started. To date, only a handful of ATP-mimetic compounds have been demonstrated to be selective inhibitors of SGK1 (Figure 2).

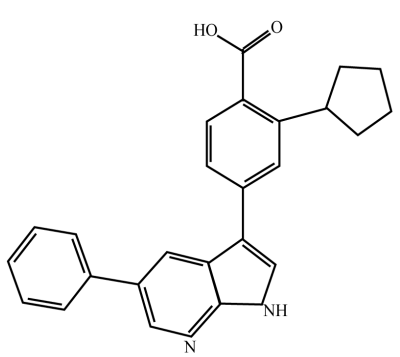

GSK650394

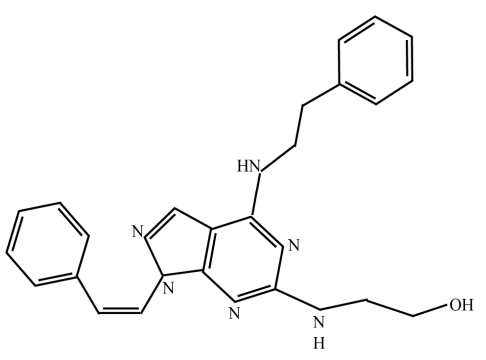

SI113<smiles>CCc1c(C(=O)NNC(=O)C(O)c2cc(F)cc(F)c2)ccc(O)c1C</smiles>

EMD638683<smiles>Nc1n[nH]c2cc(-c3ccc(NS(=O)(=O)c4cccc(Cl)c4Cl)cc3)cnc12</smiles>

SGK1-inh

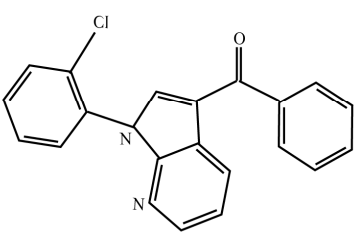

QGY-5-114-A

Figure 2. Chemical structure of small molecules capable of inhibiting SGK1.

While these compounds did help to elucidate some of the SGK1-specific downstream targets, their use in clinical settings has been limited because of low specificity, modest bioavailability, and reduced cell permeability. 
The most used SGK-1 inhibitor, GSK650394, was described for the first time in 2008 by Sherk et al. [236]. Chemically, it is a heterocyclic derivative of indazole with relatively poor cell permeability [237]. In testing its specificity, the authors reported that the observed $\mathrm{IC}_{50}$ was similar for SGK1 and SGK2 (62 and $103 \mathrm{nM}$, respectively). Moreover, this compound has been found to have off-targets in subsequent studies. In particular, it has been shown to be only less than 10-fold more selective for SGK1 than for Aurora and c-Jun N-terminal kinase and only 30-fold for IGF1R, ROCK, JAK1 and JAK3, AKT1/2/3, DYRK1A, and PDK1 [238].

In 2011, a benzohydrazide derivative, later labeled as EMD638683, was described by Ackermann et al. [239] as an SGK1 inhibitor with an in vitro $\mathrm{IC}_{50}$ of $3 \mu \mathrm{M}$. The authors also evaluated it for in vivo use. However, the effective dose needed was rather high $(600 \mathrm{mg} / \mathrm{Kg})$. EMD638683 seemed to be slightly more selective than GSK650394 in terms of off-targeting. However, both compounds needed to be used at $10 \mu \mathrm{M}$ or higher concentrations to observe a significant decrease in NDRG1 phosphorylation. Additionally, EMD638683 inhibits MSK1 and PRK2 with an efficiency similar than that of SGK1, SGK2, or SGK3 [239].

More recently, Ortuso et al. reported the identification of a novel SGK1 inhibitor now named SI113. Based on the Pyrazolo-Pyrimidine Scaffold, SI113 showed remarkable selectivity for SGK1 when tested in comparison with AKT1. Although preclinical reports suggested low toxicity, this inhibitor has not been commercialized yet [206,240].

Halland et al., in 2015, described N-[4-(1H-Pyrazolo [3,4-b]pyrazin-6-yl)-phenyl]-sulfonamides as SGK1 inhibitors and, in particular, the compound " $14 \mathrm{~g}$ ", which was renamed one year later as "SGK1-inh" by Castel et al. Although this compound has a reported $\mathrm{IC}_{50}$ of $4.8 \mathrm{nM}$ for SGK1 inhibition, its use is significantly limited by poor cell permeability. Consequently, high doses are required to achieve a significant effect on NDRG1 (>10 $\mu$ M) [12,241,242].

Lastly, QGY-5-114-A was developed as an analog of GSK650394 and has recently been reported by Liang et al. to have a reasonably low $\mathrm{IC}_{50}$ and to show promising in vivo results in xenograft models [243].

What is important for the identification of compounds capable of inhibiting SGK1 is the development of specific activity assays. Currently, the effect of SGK1 activity candidate inhibitors has been assessed with methods broadly used for other kinases, usually by measuring $\left[\gamma_{-}{ }^{32} \mathrm{P}\right]$ ATP incorporation into a substrate peptide [12].

An interesting variation of the same principle was applied by Bezzerides et al., who developed an assay based on a phosphorylated peptide labeled with a green, fluorescent dye. SGK1 activity was, in this case, assessed by measuring the increase in the value of fluorescence polarization upon binding with a phospho-specific antibody [244].

As evidence of the relevance of SGK1 in cancer increases, more inhibitors are expected to be developed for testing in the clinics. The biggest obstacle to achieve this goal does not appear to be specificity of targeting, but better pharmacodynamics.

\section{Conclusions}

Although identified and initially characterized in 1993 [70], SGK1 is only recently being recognized as an essential mediator in a variety of processes, far more diverse than originally thought.

Most importantly, SGK1 is overexpressed in cancer and consistent evidence suggests that SGK1 can be a prognostic factor and a potential therapeutic target for the treatment of NSCLC. However, further studies are required to better assess its role in NSCLC pathogenesis and treatment response. While it is certainly true that efforts should be made towards the identification of new selective inhibitors of SGK1 suitable for in vivo studies, it is even more important to fully unravel the intricate network of functional interactions that this kinase operates in. To this end, the use of SGK1 conditional mouse models will be paramount to clarify direct and specific SGK1 targets. Their use will be essential to define cell autonomous vs. non-cell autonomous SGK1 functions connected with NSCLC development and progression. 
Author Contributions: Conceptualization, A.O. and V.C.; writing—original draft preparation, A.O., I.G. and G.M.; writing-review and editing, A.O., I.G., G.M. and V.C.; supervision, A.O. All authors have read and agreed to the published version of the manuscript.

Funding: This research received no external funding.

Acknowledgments: Graphical abstract created with BioRender.com (https://biorender.com).

Conflicts of Interest: The authors declare no conflict of interest.

\section{References}

1. Bray, F.; Ferlay, J.; Soerjomataram, I.; Siegel, R.L.; Torre, L.A.; Jemal, A. Global cancer statistics 2018: GLOBOCAN estimates of incidence and mortality worldwide for 36 cancers in 185 countries. CA Cancer J. Clin. 2018, 68, 394-424. [CrossRef] [PubMed]

2. Inamura, K. Lung Cancer: Understanding Its Molecular Pathology and the 2015 WHO Classification. Front. Oncol. 2017, 7, 193. [CrossRef] [PubMed]

3. Travis, W.D.; Brambilla, E.; Nicholson, A.G.; Yatabe, Y.; Austin, J.H.M.; Beasley, M.B.; Chirieac, L.R.; Dacic, S.; Duhig, E.; Flieder, D.B.; et al. The 2015 World Health Organization Classification of Lung Tumors: Impact of Genetic, Clinical and Radiologic Advances Since the 2004 Classification. J. Thorac. Oncol. 2015, 10, 1243-1260. [CrossRef] [PubMed]

4. Kuhn, E.; Morbini, P.; Cancellieri, A.; Damiani, S.; Cavazza, A.; Comin, C.E. Adenocarcinoma classification: Patterns and prognosis. Pathologica 2018, 110, 5-11. [PubMed]

5. Park, H.J.; Cha, Y.J.; Kim, S.H.; Kim, A.; Kim, E.Y.; Chang, Y.S. Keratinization of Lung Squamous Cell Carcinoma Is Associated with Poor Clinical Outcome. Tuberc. Respir. Dis. (Seoul) 2017, 80, 179-186. [CrossRef] [PubMed]

6. Pelosi, G.; Barbareschi, M.; Cavazza, A.; Graziano, P.; Rossi, G.; Papotti, M. Large cell carcinoma of the lung: A tumor in search of an author. A clinically oriented critical reappraisal. Lung Cancer 2015, 87, 226-231. [CrossRef] [PubMed]

7. Herbst, R.S.; Morgensztern, D.; Boshoff, C. The biology and management of non-small cell lung cancer. Nature 2018, 553, 446-454. [CrossRef]

8. Chen, Z.; Fillmore, C.M.; Hammerman, P.S.; Kim, C.F.; Wong, K.K. Non-small-cell lung cancers: A heterogeneous set of diseases. Nat. Rev. Cancer 2014, 14, 535-546. [CrossRef]

9. Zhang, Y.; Kwok-Shing Ng, P.; Kucherlapati, M.; Chen, F.; Liu, Y.; Tsang, Y.H.; de Velasco, G.; Jeong, K.J.; Akbani, R.; Hadjipanayis, A.; et al. A Pan-Cancer Proteogenomic Atlas of PI3K/AKT/mTOR Pathway Alterations. Cancer Cell 2017, 31, 820-832.e823. [CrossRef]

10. Millis, S.Z.; Ikeda, S.; Reddy, S.; Gatalica, Z.; Kurzrock, R. Landscape of Phosphatidylinositol-3-Kinase Pathway Alterations Across 19784 Diverse Solid Tumors. JAMA Oncol. 2016, 2, 1565-1573. [CrossRef]

11. Vasudevan, K.M.; Barbie, D.A.; Davies, M.A.; Rabinovsky, R.; McNear, C.J.; Kim, J.J.; Hennessy, B.T.; Tseng, H.; Pochanard, P.; Kim, S.Y.; et al. AKT-independent signaling downstream of oncogenic PIK3CA mutations in human cancer. Cancer Cell 2009, 16, 21-32. [CrossRef] [PubMed]

12. Castel, P.; Ellis, H.; Bago, R.; Toska, E.; Razavi, P.; Carmona, F.J.; Kannan, S.; Verma, C.S.; Dickler, M.; Chandarlapaty, S.; et al. PDK1-SGK1 Signaling Sustains AKT-Independent mTORC1 Activation and Confers Resistance to PI3Kalpha Inhibition. Cancer Cell 2016, 30, 229-242. [CrossRef] [PubMed]

13. Sommer, E.M.; Dry, H.; Cross, D.; Guichard, S.; Davies, B.R.; Alessi, D.R. Elevated SGK1 predicts resistance of breast cancer cells to Akt inhibitors. Biochem. J. 2013, 452, 499-508. [CrossRef] [PubMed]

14. Matikas, A.; Mistriotis, D.; Georgoulias, V.; Kotsakis, A. Current and Future Approaches in the Management of Non-Small-Cell Lung Cancer Patients With Resistance to EGFR TKIs. Clin. Lung Cancer 2015, 16, 252-261. [CrossRef]

15. Tang, Z.H.; Lu, J.J. Osimertinib resistance in non-small cell lung cancer: Mechanisms and therapeutic strategies. Cancer Lett. 2018, 420, 242-246. [CrossRef]

16. Ricciuti, B.; De Giglio, A.; Mecca, C.; Arcuri, C.; Marini, S.; Metro, G.; Baglivo, S.; Sidoni, A.; Bellezza, G.; Crino, L.; et al. Precision medicine against ALK-positive non-small cell lung cancer: Beyond crizotinib. Med. Oncol. 2018, 35, 72. [CrossRef] 
17. Basit, S.; Ashraf, Z.; Lee, K.; Latif, M. First macrocyclic 3(rd)-generation ALK inhibitor for treatment of ALK/ROS1 cancer: Clinical and designing strategy update of lorlatinib. Eur. J. Med. Chem. 2017, 134, 348-356. [CrossRef]

18. Planchard, D.; Smit, E.F.; Groen, H.J.M.; Mazieres, J.; Besse, B.; Helland, A.; Giannone, V.; D’Amelio, A.M., Jr.; Zhang, P.; Mookerjee, B.; et al. Dabrafenib plus trametinib in patients with previously untreated BRAF(V600E)-mutant metastatic non-small-cell lung cancer: An open-label, phase 2 trial. Lancet Oncol. 2017, 18, 1307-1316. [CrossRef]

19. Chan, B.A.; Hughes, B.G. Targeted therapy for non-small cell lung cancer: Current standards and the promise of the future. Transl. Lung Cancer Res. 2015, 4, 36-54. [CrossRef]

20. Chen, C.; Peng, S.; Li, P.; Ma, L.; Gan, X. High expression of NEK2 promotes lung cancer progression and drug resistance and is regulated by mutant EGFR. Mol. Cell. Biochem. 2020. [CrossRef]

21. Kayatani, H.; Ohashi, K.; Ninomiya, K.; Makimoto, G.; Nishii, K.; Higo, H.; Watanabe, H.; Kano, H.; Kato, Y.; Ninomiya, T.; et al. Beneficial effect of erlotinib and trastuzumab emtansine combination in lung tumors harboring EGFR mutations. Biochem. Biophys. Res. Commun. 2020. [CrossRef] [PubMed]

22. Zheng, J.; Sun, W.; Chen, W.; Zhou, J.; Zhou, J. Sustained Response to Crizotinib After Resistance to First-Line Alectinib Treatment in Two Patients With ALK-Rearranged NSCLC. J. Thorac. Oncol. 2020, 15, e150-e153. [CrossRef] [PubMed]

23. Urban, L.; Doczi, R.; Vodicska, B.; Kormos, D.; Toth, L.; Takacs, I.; Varkondi, E.; Tihanyi, D.; Lakatos, D.; Dirner, A.; et al. Efficacy of Incremental Next-Generation ALK Inhibitor Treatment in Oncogene-Addicted, ALK-Positive, TP53-Mutant NSCLC. J. Pers. Med. 2020, 10, 107. [CrossRef] [PubMed]

24. Singh, A.; Chen, H. Optimal Care for Patients with Anaplastic Lymphoma Kinase (ALK)-Positive Non-Small Cell Lung Cancer: A Review on the Role and Utility of ALK Inhibitors. Cancer Manag. Res. 2020, 12, 6615-6628. [CrossRef] [PubMed]

25. Lee, J.; Park, S.; Jung, H.A.; Sun, J.M.; Lee, S.H.; Ahn, J.S.; Park, K.; Ahn, M.J. Evaluating entrectinib as a treatment option for non-small cell lung cancer. Expert Opin. Pharmacother. 2020, 1-8. [CrossRef] [PubMed]

26. Kobayashi, T.; Cohen, P. Activation of serum- and glucocorticoid-regulated protein kinase by agonists that activate phosphatidylinositide 3-kinase is mediated by 3-phosphoinositide-dependent protein kinase-1 (PDK1) and PDK2. Biochem. J. 1999, 339, 319-328. [CrossRef] [PubMed]

27. Park, J.; Leong, M.L.; Buse, P.; Maiyar, A.C.; Firestone, G.L.; Hemmings, B.A. Serum and glucocorticoidinducible kinase (SGK) is a target of the PI 3-kinase-stimulated signaling pathway. EMBO J. 1999, 18, 3024-3033. [CrossRef]

28. Milburn, C.C.; Deak, M.; Kelly, S.M.; Price, N.C.; Alessi, D.R.; Van Aalten, D.M. Binding of phosphatidylinositol 3,4,5-trisphosphate to the pleckstrin homology domain of protein kinase B induces a conformational change. Biochem. J. 2003, 375, 531-538. [CrossRef]

29. Yan, L.; Mieulet, V.; Lamb, R.F. mTORC2 is the hydrophobic motif kinase for SGK1. Biochem. J. 2008, 416, e19-e21. [CrossRef]

30. Garcia-Martinez, J.M.; Alessi, D.R. mTOR complex 2 (mTORC2) controls hydrophobic motif phosphorylation and activation of serum- and glucocorticoid-induced protein kinase 1 (SGK1). Biochem. J. 2008, 416, 375-385. [CrossRef]

31. Biondi, R.M.; Kieloch, A.; Currie, R.A.; Deak, M.; Alessi, D.R. The PIF-binding pocket in PDK1 is essential for activation of S6K and SGK, but not PKB. EMBO J. 2001, 20, 4380-4390. [CrossRef] [PubMed]

32. Lang, F.; Bohmer, C.; Palmada, M.; Seebohm, G.; Strutz-Seebohm, N.; Vallon, V. (Patho)physiological significance of the serum- and glucocorticoid-inducible kinase isoforms. Physiol. Rev. 2006, 86, 1151-1178. [CrossRef] [PubMed]

33. Loffing, J.; Flores, S.Y.; Staub, O. Sgk kinases and their role in epithelial transport. Annu. Rev. Physiol. 2006, 68, 461-490. [CrossRef] [PubMed]

34. Salker, M.S.; Christian, M.; Steel, J.H.; Nautiyal, J.; Lavery, S.; Trew, G.; Webster, Z.; Al-Sabbagh, M.; Puchchakayala, G.; Foller, M.; et al. Deregulation of the serum- and glucocorticoid-inducible kinase SGK1 in the endometrium causes reproductive failure. Nat. Med. 2011, 17, 1509-1513. [CrossRef] [PubMed]

35. Heikamp, E.B.; Patel, C.H.; Collins, S.; Waickman, A.; Oh, M.H.; Sun, I.H.; Illei, P.; Sharma, A.; Naray-Fejes-Toth, A.; Fejes-Toth, G.; et al. The AGC kinase SGK1 regulates TH1 and TH2 differentiation downstream of the mTORC2 complex. Nat. Immunol. 2014, 15, 457-464. [CrossRef] 
36. Li, B.; Tournier, C.; Davis, R.J.; Flavell, R.A. Regulation of IL-4 expression by the transcription factor JunB during T helper cell differentiation. EMBO J. 1999, 18, 420-432. [CrossRef]

37. Liu, H.; Yu, J.; Xia, T.; Xiao, Y.; Zhang, Q.; Liu, B.; Guo, Y.; Deng, J.; Deng, Y.; Chen, S.; et al. Hepatic serum- and glucocorticoid-regulated protein kinase 1 (SGK1) regulates insulin sensitivity in mice via extracellular-signal-regulated kinase 1/2 (ERK1/2). Biochem. J. 2014, 464, 281-289. [CrossRef]

38. Kulkarni, S.; Goel-Bhattacharya, S.; Sengupta, S.; Cochran, B.H. A Large-Scale RNAi Screen Identifies SGK1 as a Key Survival Kinase for GBM Stem Cells. Mol. Cancer Res. 2018, 16, 103-114. [CrossRef]

39. Lang, F.; Stournaras, C. Serum and glucocorticoid inducible kinase, metabolic syndrome, inflammation, and tumor growth. Hormones (Athens) 2013, 12, 160-171. [CrossRef]

40. Inoue, K.; Leng, T.; Yang, T.; Zeng, Z.; Ueki, T.; Xiong, Z.G. Role of serum- and glucocorticoid-inducible kinases in stroke. J. Neurochem. 2016, 138, 354-361. [CrossRef]

41. Lang, F.; Gorlach, A.; Vallon, V. Targeting SGK1 in diabetes. Expert Opin. Ther. Targets 2009, 13, $1303-1311$. [CrossRef] [PubMed]

42. Fagerli, U.M.; Ullrich, K.; Stuhmer, T.; Holien, T.; Kochert, K.; Holt, R.U.; Bruland, O.; Chatterjee, M.; Nogai, H.; Lenz, G.; et al. Serum/glucocorticoid-regulated kinase 1 (SGK1) is a prominent target gene of the transcriptional response to cytokines in multiple myeloma and supports the growth of myeloma cells. Oncogene 2011, 30, 3198-3206. [CrossRef] [PubMed]

43. Orlacchio, A.; Ranieri, M.; Brave, M.; Arciuch, V.A.; Forde, T.; De Martino, D.; Anderson, K.E.; Hawkins, P.; Di Cristofano, A. SGK1 Is a Critical Component of an AKT-Independent Pathway Essential for PI3K-Mediated Tumor Development and Maintenance. Cancer Res. 2017, 77, 6914-6926. [CrossRef]

44. Melhem, A.; Yamada, S.D.; Fleming, G.F.; Delgado, B.; Brickley, D.R.; Wu, W.; Kocherginsky, M.; Conzen, S.D. Administration of glucocorticoids to ovarian cancer patients is associated with expression of the anti-apoptotic genes SGK1 and MKP1/DUSP1 in ovarian tissues. Clin. Cancer Res. 2009, 15, 3196-3204. [CrossRef]

45. Lang, F.; Cohen, P. Regulation and physiological roles of serum- and glucocorticoid-induced protein kinase isoforms. Sci. STKE 2001, 2001, re17. [CrossRef] [PubMed]

46. Firestone, G.L.; Giampaolo, J.R.; O'Keeffe, B.A. Stimulus-dependent regulation of serum and glucocorticoid inducible protein kinase (SGK) transcription, subcellular localization and enzymatic activity. Cell. Physiol. Biochem. 2003, 13, 1-12. [CrossRef]

47. Kobayashi, T.; Deak, M.; Morrice, N.; Cohen, P. Characterization of the structure and regulation of two novel isoforms of serum- and glucocorticoid-induced protein kinase. Biochem. J. 1999, 344 Pt 1, 189-197. [CrossRef] [PubMed]

48. Maestro, I.; Boya, P.; Martinez, A. Serum- and glucocorticoid-induced kinase 1, a new therapeutic target for autophagy modulation in chronic diseases. Expert Opin. Ther. Targets 2020, 24, 231-243. [CrossRef]

49. Bago, R.; Malik, N.; Munson, M.J.; Prescott, A.R.; Davies, P.; Sommer, E.; Shpiro, N.; Ward, R.; Cross, D.; Ganley, I.G.; et al. Characterization of VPS34-IN1, a selective inhibitor of Vps34, reveals that the phosphatidylinositol 3-phosphate-binding SGK3 protein kinase is a downstream target of class III phosphoinositide 3-kinase. Biochem. J. 2014, 463, 413-427. [CrossRef]

50. Arteaga, M.F.; Alvarez de la Rosa, D.; Alvarez, J.A.; Canessa, C.M. Multiple translational isoforms give functional specificity to serum- and glucocorticoid-induced kinase 1. Mol. Biol. Cell 2007, 18, 2072-2080. [CrossRef]

51. Bogusz, A.M.; Brickley, D.R.; Pew, T.; Conzen, S.D. A novel N-terminal hydrophobic motif mediates constitutive degradation of serum- and glucocorticoid-induced kinase-1 by the ubiquitin-proteasome pathway. FEBS J. 2006, 273, 2913-2928. [CrossRef] [PubMed]

52. Belova, L.; Sharma, S.; Brickley, D.R.; Nicolarsen, J.R.; Patterson, C.; Conzen, S.D. Ubiquitin-proteasome degradation of serum- and glucocorticoid-regulated kinase-1 (SGK-1) is mediated by the chaperonedependent E3 ligase CHIP. Biochem. J. 2006, 400, 235-244. [CrossRef] [PubMed]

53. Raikwar, N.S.; Snyder, P.M.; Thomas, C.P. An evolutionarily conserved N-terminal Sgk1 variant with enhanced stability and improved function. Am. J. Physiol. Ren. Physiol. 2008, 295, F1440-F1448. [CrossRef] [PubMed]

54. Arteaga, M.F.; Coric, T.; Straub, C.; Canessa, C.M. A brain-specific SGK1 splice isoform regulates expression of ASIC1 in neurons. Proc. Natl. Acad. Sci. USA 2008, 105, 4459-4464. [CrossRef] [PubMed] 
55. Gonzalez-Fernandez, R.; Avila, J.; Arteaga, M.F.; Canessa, C.M.; Martin-Vasallo, P. The neuronal-specific SGK1.1 (SGK1_v2) kinase as a transcriptional modulator of BAG4, Brox, and PPP1CB genes expression. Int. J. Mol. Sci. 2015, 16, 7462-7477. [CrossRef] [PubMed]

56. Wulff, P.; Vallon, V.; Huang, D.Y.; Volkl, H.; Yu, F.; Richter, K.; Jansen, M.; Schlunz, M.; Klingel, K.; Loffing, J.; et al. Impaired renal $\mathrm{Na}(+)$ retention in the sgk1-knockout mouse. J. Clin. Investig. 2002, 110, 1263-1268. [CrossRef]

57. Huang, D.Y.; Wulff, P.; Volkl, H.; Loffing, J.; Richter, K.; Kuhl, D.; Lang, F.; Vallon, V. Impaired regulation of renal $\mathrm{K}+$ elimination in the sgk1-knockout mouse. J. Am. Soc. Nephrol. 2004, 15, 885-891. [CrossRef]

58. Sandulache, D.; Grahammer, F.; Artunc, F.; Henke, G.; Hussain, A.; Nasir, O.; Mack, A.; Friedrich, B.; Vallon, V.; Wulff, P.; et al. Renal Ca2+ handling in sgk1 knockout mice. Pflug. Arch. 2006, 452, 444-452. [CrossRef]

59. Huang, D.Y.; Boini, K.M.; Friedrich, B.; Metzger, M.; Just, L.; Osswald, H.; Wulff, P.; Kuhl, D.; Vallon, V.; Lang, F. Blunted hypertensive effect of combined fructose and high-salt diet in gene-targeted mice lacking functional serum- and glucocorticoid-inducible kinase SGK1. Am. J. Physiol. Regul. Integr. Comp. Physiol. 2006, 290, R935-R944. [CrossRef]

60. Huang, D.Y.; Boini, K.M.; Osswald, H.; Friedrich, B.; Artunc, F.; Ullrich, S.; Rajamanickam, J.; Palmada, M.; Wulff, P.; Kuhl, D.; et al. Resistance of mice lacking the serum- and glucocorticoid-inducible kinase SGK1 against salt-sensitive hypertension induced by a high-fat diet. Am. J. Physiol. Ren. Physiol. 2006, 291, F1264-F1273. [CrossRef]

61. Vallon, V.; Huang, D.Y.; Grahammer, F.; Wyatt, A.W.; Osswald, H.; Wulff, P.; Kuhl, D.; Lang, F. SGK1 as a determinant of kidney function and salt intake in response to mineralocorticoid excess. Am. J. Physiol. Regul. Integr. Comp. Physiol. 2005, 289, R395-R401. [CrossRef] [PubMed]

62. Grahammer, F.; Henke, G.; Sandu, C.; Rexhepaj, R.; Hussain, A.; Friedrich, B.; Risler, T.; Metzger, M.; Just, L.; Skutella, T.; et al. Intestinal function of gene-targeted mice lacking serum- and glucocorticoid-inducible kinase 1. Am. J. Physiol. Gastrointest. Liver Physiol. 2006, 290, G1114-G1123. [CrossRef] [PubMed]

63. Boini, K.M.; Hennige, A.M.; Huang, D.Y.; Friedrich, B.; Palmada, M.; Boehmer, C.; Grahammer, F.; Artunc, F.; Ullrich, S.; Avram, D.; et al. Serum- and glucocorticoid-inducible kinase 1 mediates salt sensitivity of glucose tolerance. Diabetes 2006, 55, 2059-2066. [CrossRef] [PubMed]

64. Schmidt, E.M.; Kraemer, B.F.; Borst, O.; Munzer, P.; Schonberger, T.; Schmidt, C.; Leibrock, C.; Towhid, S.T.; Seizer, P.; Kuhl, D.; et al. SGK1 sensitivity of platelet migration. Cell Physiol. Biochem. 2012, 30, 259-268. [CrossRef]

65. McCormick, J.A.; Feng, Y.; Dawson, K.; Behne, M.J.; Yu, B.; Wang, J.; Wyatt, A.W.; Henke, G.; Grahammer, F.; Mauro, T.M.; et al. Targeted disruption of the protein kinase SGK3/CISK impairs postnatal hair follicle development. Mol. Biol. Cell 2004, 15, 4278-4288. [CrossRef]

66. Lang, U.E.; Wolfer, D.P.; Grahammer, F.; Strutz-Seebohm, N.; Seebohm, G.; Lipp, H.P.; McCormick, J.A.; Hellweg, R.; Dawson, K.; Wang, J.; et al. Reduced locomotion in the serum and glucocorticoid inducible kinase 3 knock out mouse. Behav. Brain Res. 2006, 167, 75-86. [CrossRef]

67. Grahammer, F.; Artunc, F.; Sandulache, D.; Rexhepaj, R.; Friedrich, B.; Risler, T.; McCormick, J.A.; Dawson, K.; Wang, J.; Pearce, D.; et al. Renal function of gene-targeted mice lacking both SGK1 and SGK3. Am. J. Physiol. Regul. Integr. Comp. Physiol. 2006, 290, R945-R950. [CrossRef]

68. Schnackenberg, C.; Costell, M.H.; Bernard, R.E.; Minuti, K.K.; Grygielko, E.T.; Parsons, M.J.; Laping, N.J.; Duddy, G. Compensatory role for Sgk2 mediated sodium reabsorption during salt deprivation in Sgk1 knockout mice. FASEB J. 2007, 21, A508. [CrossRef]

69. Bruhn, M.A.; Pearson, R.B.; Hannan, R.D.; Sheppard, K.E. AKT-independent PI3-K signaling in cancer-Emerging role for SGK3. Cancer Manag. Res. 2013, 5, 281-292. [CrossRef]

70. Webster, M.K.; Goya, L.; Ge, Y.; Maiyar, A.C.; Firestone, G.L. Characterization of sgk, a novel member of the serine/threonine protein kinase gene family which is transcriptionally induced by glucocorticoids and serum. Mol. Cell. Biol. 1993, 13, 2031-2040. [CrossRef]

71. Bhargava, A.; Wang, J.; Pearce, D. Regulation of epithelial ion transport by aldosterone through changes in gene expression. Mol. Cell. Endocrinol. 2004, 217, 189-196. [CrossRef] [PubMed]

72. Mizuno, H.; Nishida, E. The ERK MAP kinase pathway mediates induction of SGK (serum- and glucocorticoid-inducible kinase) by growth factors. Genes Cells 2001, 6, 261-268. [CrossRef] [PubMed] 
73. Yang, C.; Li, J.; Sun, F.; Zhou, H.; Yang, J.; Yang, C. The functional duality of SGK1 in the regulation of hyperglycemia. Endocr. Connect. 2020, 9, R187-R194. [CrossRef] [PubMed]

74. Hayashi, M.; Tapping, R.I.; Chao, T.H.; Lo, J.F.; King, C.C.; Yang, Y.; Lee, J.D. BMK1 mediates growth factor-induced cell proliferation through direct cellular activation of serum and glucocorticoid-inducible kinase. J. Biol. Chem. 2001, 276, 8631-8634. [CrossRef]

75. Meng, F.; Yamagiwa, Y.; Taffetani, S.; Han, J.; Patel, T. IL-6 activates serum and glucocorticoid kinase via p38alpha mitogen-activated protein kinase pathway. Am. J. Physiol. Cell Physiol. 2005, 289, C971-C981. [CrossRef]

76. You, H.; Jang, Y.; You-Ten, A.I.; Okada, H.; Liepa, J.; Wakeham, A.; Zaugg, K.; Mak, T.W. p53-dependent inhibition of FKHRL1 in response to DNA damage through protein kinase SGK1. Proc. Natl. Acad. Sci. USA 2004, 101, 14057-14062. [CrossRef]

77. Baban, B.; Liu, J.Y.; Mozaffari, M.S. SGK-1 regulates inflammation and cell death in the ischemic-reperfused heart: Pressure-related effects. Am. J. Hypertens. 2014, 27, 846-856. [CrossRef]

78. Amato, R.; Menniti, M.; Agosti, V.; Boito, R.; Costa, N.; Bond, H.M.; Barbieri, V.; Tagliaferri, P.; Venuta, S.; Perrotti, N. IL-2 signals through Sgk1 and inhibits proliferation and apoptosis in kidney cancer cells. J. Mol. Med. 2007, 85, 707-721. [CrossRef]

79. Cowling, R.T.; Birnboim, H.C. Expression of serum- and glucocorticoid-regulated kinase (sgk) mRNA is up-regulated by GM-CSF and other proinflammatory mediators in human granulocytes. J. Leukoc. Biol. 2000, 67, 240-248. [CrossRef]

80. Chen, S.Y.; Bhargava, A.; Mastroberardino, L.; Meijer, O.C.; Wang, J.; Buse, P.; Firestone, G.L.; Verrey, F.; Pearce, D. Epithelial sodium channel regulated by aldosterone-induced protein sgk. Proc. Natl. Acad. Sci. USA 1999, 96, 2514-2519. [CrossRef]

81. Waldegger, S.; Klingel, K.; Barth, P.; Sauter, M.; Rfer, M.L.; Kandolf, R.; Lang, F. h-sgk serine-threonine protein kinase gene as transcriptional target of transforming growth factor beta in human intestine. Gastroenterology 1999, 116, 1081-1088. [CrossRef]

82. Richards, J.S.; Sharma, S.C.; Falender, A.E.; Lo, Y.H. Expression of FKHR, FKHRL1, and AFX genes in the rodent ovary: Evidence for regulation by IGF-I, estrogen, and the gonadotropins. Mol. Endocrinol. 2002, 16, 580-599. [CrossRef] [PubMed]

83. Alliston, T.N.; Gonzalez-Robayna, I.J.; Buse, P.; Firestone, G.L.; Richards, J.S. Expression and localization of serum/glucocorticoid-induced kinase in the rat ovary: Relation to follicular growth and differentiation. Endocrinology 2000, 141, 385-395. [CrossRef] [PubMed]

84. Perrotti, N.; He, R.A.; Phillips, S.A.; Haft, C.R.; Taylor, S.I. Activation of serum- and glucocorticoid-induced protein kinase (Sgk) by cyclic AMP and insulin. J. Biol. Chem. 2001, 276, 9406-9412. [CrossRef] [PubMed]

85. Waldegger, S.; Barth, P.; Raber, G.; Lang, F. Cloning and characterization of a putative human serine/threonine protein kinase transcriptionally modified during anisotonic and isotonic alterations of cell volume. Proc. Natl. Acad. Sci. USA 1997, 94, 4440-4445. [CrossRef] [PubMed]

86. Leong, M.L.; Maiyar, A.C.; Kim, B.; O'Keeffe, B.A.; Firestone, G.L. Expression of the serum- and glucocorticoid-inducible protein kinase, Sgk, is a cell survival response to multiple types of environmental stress stimuli in mammary epithelial cells. J. Biol. Chem. 2003, 278, 5871-5882. [CrossRef] [PubMed]

87. Imaizumi, K.; Tsuda, M.; Wanaka, A.; Tohyama, M.; Takagi, T. Differential expression of sgk mRNA, a member of the Ser/Thr protein kinase gene family, in rat brain after CNS injury. Brain Res. Mol. Brain Res. 1994, 26, 189-196. [CrossRef]

88. Fillon, S.; Klingel, K.; Warntges, S.; Sauter, M.; Gabrysch, S.; Pestel, S.; Tanneur, V.; Waldegger, S.; Zipfel, A.; Viebahn, R.; et al. Expression of the serine/threonine kinase hSGK1 in chronic viral hepatitis. Cell. Physiol. Biochem. 2002, 12, 47-54. [CrossRef]

89. Bell, L.M.; Leong, M.L.; Kim, B.; Wang, E.; Park, J.; Hemmings, B.A.; Firestone, G.L. Hyperosmotic stress stimulates promoter activity and regulates cellular utilization of the serum- and glucocorticoid-inducible protein kinase (Sgk) by a p38 MAPK-dependent pathway. J. Biol. Chem. 2000, 275, 25262-25272. [CrossRef]

90. Lang, F.; Klingel, K.; Wagner, C.A.; Stegen, C.; Warntges, S.; Friedrich, B.; Lanzendorfer, M.; Melzig, J.; Moschen, I.; Steuer, S.; et al. Deranged transcriptional regulation of cell-volume-sensitive kinase hSGK in diabetic nephropathy. Proc. Natl. Acad. Sci. USA 2000, 97, 8157-8162. [CrossRef] 
91. Arteaga, M.F.; Wang, L.; Ravid, T.; Hochstrasser, M.; Canessa, C.M. An amphipathic helix targets serum and glucocorticoid-induced kinase 1 to the endoplasmic reticulum-associated ubiquitin-conjugation machinery. Proc. Natl. Acad. Sci. USA 2006, 103, 11178-11183. [CrossRef] [PubMed]

92. Wiemuth, D.; Lott, J.S.; Ly, K.; Ke, Y.; Teesdale-Spittle, P.; Snyder, P.M.; McDonald, F.J. Interaction of serumand glucocorticoid regulated kinase 1 (SGK1) with the WW-domains of Nedd4-2 is required for epithelial sodium channel regulation. PLoS ONE 2010, 5, e12163. [CrossRef] [PubMed]

93. Asher, C.; Sinha, I.; Garty, H. Characterization of the interactions between Nedd4-2, ENaC, and sgk-1 using surface plasmon resonance. Biochim. Biophys. Acta 2003, 1612, 59-64. [CrossRef]

94. Brickley, D.R.; Mikosz, C.A.; Hagan, C.R.; Conzen, S.D. Ubiquitin modification of serum and glucocorticoid-induced protein kinase-1 (SGK-1). J. Biol. Chem. 2002, 277, 43064-43070. [CrossRef] [PubMed]

95. Zhou, R.; Snyder, P.M. Nedd4-2 phosphorylation induces serum and glucocorticoid-regulated kinase (SGK) ubiquitination and degradation. J. Biol. Chem. 2005, 280, 4518-4523. [CrossRef] [PubMed]

96. Gao, D.; Wan, L.; Inuzuka, H.; Berg, A.H.; Tseng, A.; Zhai, B.; Shaik, S.; Bennett, E.; Tron, A.E.; Gasser, J.A.; et al. Rictor forms a complex with Cullin-1 to promote SGK1 ubiquitination and destruction. Mol. Cell 2010, 39, 797-808. [CrossRef] [PubMed]

97. Gao, D.; Wan, L.; Wei, W. Phosphorylation of Rictor at Thr1135 impairs the Rictor/Cullin-1 complex to ubiquitinate SGK1. Protein Cell 2010, 1, 881-885. [CrossRef]

98. Soundararajan, R.; Wang, J.; Melters, D.; Pearce, D. Glucocorticoid-induced Leucine zipper 1 stimulates the epithelial sodium channel by regulating serum- and glucocorticoid-induced kinase 1 stability and subcellular localization. J. Biol. Chem. 2010, 285, 39905-39913. [CrossRef]

99. Luginbuhl, J.; Sivaraman, D.M.; Shin, J.W. The essentiality of non-coding RNAs in cell reprogramming. Noncoding RNA Res. 2017, 2, 74-82. [CrossRef]

100. Wu, K.L.; Tsai, Y.M.; Lien, C.T.; Kuo, P.L.; Hung, A.J. The Roles of MicroRNA in Lung Cancer. Int. J. Mol. Sci. 2019, 20, 1611. [CrossRef]

101. Zheng, Y.Y.; Fei, Y.; Wang, Z.; Chen, Y.; Qiu, C.; Li, F.R. Tissue microRNAs in non-small cell lung cancer detected with a new kind of liquid bead array detection system. J. Transl. Med. 2020, 18, 108. [CrossRef] [PubMed]

102. Liao, J.; Shen, J.; Leng, Q.; Qin, M.; Zhan, M.; Jiang, F. MicroRNA-based biomarkers for diagnosis of non-small cell lung cancer (NSCLC). Thorac. Cancer 2020, 11, 762-768. [CrossRef] [PubMed]

103. Lu, J.; Zhan, Y.; Feng, J.; Luo, J.; Fan, S. MicroRNAs associated with therapy of non-small cell lung cancer. Int. J. Biol. Sci. 2018, 14, 390-397. [CrossRef] [PubMed]

104. Available online: http://mirwalk.umm.uni-heidelberg.de (accessed on 27 October 2020).

105. Yang, G.; Xiong, G.; Cao, Z.; Zheng, S.; You, L.; Zhang, T.; Zhao, Y. miR-497 expression, function and clinical application in cancer. Oncotarget 2016, 7, 55900-55911. [CrossRef]

106. Zhao, W.Y.; Wang, Y.; An, Z.J.; Shi, C.G.; Zhu, G.A.; Wang, B.; Lu, M.Y.; Pan, C.K.; Chen, P. Downregulation of miR-497 promotes tumor growth and angiogenesis by targeting HDGF in non-small cell lung cancer. Biochem. Biophys. Res. Commun. 2013, 435, 466-471. [CrossRef]

107. Gu, A.; Lu, J.; Wang, W.; Shi, C.; Han, B.; Yao, M. Role of miR-497 in VEGF-A-mediated cancer cell growth and invasion in non-small cell lung cancer. Int. J. Biochem. Cell Biol. 2016, 70, 118-125. [CrossRef]

108. Han, Z.; Zhang, Y.; Yang, Q.; Liu, B.; Wu, J.; Zhang, Y.; Yang, C.; Jiang, Y. miR-497 and miR-34a retard lung cancer growth by co-inhibiting cyclin E1 (CCNE1). Oncotarget 2015, 6, 13149-13163. [CrossRef]

109. Lo Sardo, F.; Strano, S.; Blandino, G. YAP and TAZ in Lung Cancer: Oncogenic Role and Clinical Targeting. Cancers 2018, 10, 137. [CrossRef]

110. Huang, C.; Ma, R.; Yue, J.; Li, N.; Li, Z.; Qi, D. MiR-497 Suppresses YAP1 and Inhibits Tumor Growth in Non-Small Cell Lung Cancer. Cell. Physiol. Biochem. 2015, 37, 342-352. [CrossRef]

111. Wang, L.; Ji, X.B.; Wang, L.H.; Qiu, J.G.; Zhou, F.M.; Liu, W.J.; Wan, D.D.; Lin, M.C.; Liu, L.Z.; Zhang, J.Y.; et al. Regulation of MicroRNA-497-Targeting AKT2 Influences Tumor Growth and Chemoresistance to Cisplatin in Lung Cancer. Front. Cell Dev. Biol. 2020, 8, 840. [CrossRef]

112. Calin, G.A.; Dumitru, C.D.; Shimizu, M.; Bichi, R.; Zupo, S.; Noch, E.; Aldler, H.; Rattan, S.; Keating, M.; Rai, K.; et al. Frequent deletions and down-regulation of micro- RNA genes miR15 and miR16 at 13q14 in chronic lymphocytic leukemia. Proc. Natl. Acad. Sci. USA 2002, 99, 15524-15529. [CrossRef] [PubMed]

113. Yang, F.R.; Li, H.J.; Li, T.T.; Zhao, Y.F.; Liu, Z.K.; Li, X.R. Prognostic Value of MicroRNA-15a in Human Cancers: A Meta-Analysis and Bioinformatics. BioMed Res. Int. 2019, 2019, 2063823. [CrossRef] [PubMed] 
114. Bandi, N.; Vassella, E. miR-34a and miR-15a/16 are co-regulated in non-small cell lung cancer and control cell cycle progression in a synergistic and Rb-dependent manner. Mol. Cancer 2011, 10, 55. [CrossRef]

115. Wang, T.; Hou, J.; Li, Z.; Zheng, Z.; Wei, J.; Song, D.; Hu, T.; Wu, Q.; Yang, J.Y.; Cai, J.C. miR-15a-3p and miR-16-1-3p Negatively Regulate Twist1 to Repress Gastric Cancer Cell Invasion and Metastasis. Int. J. Biol. Sci. 2017, 13, 122-134. [CrossRef] [PubMed]

116. Shih, J.Y.; Yang, P.C. The EMT regulator slug and lung carcinogenesis. Carcinogenesis 2011, 32, $1299-1304$. [CrossRef]

117. Ergun, S.; Güney, S.; Temiz, E.; Petrovic, N.; Gunes, S. Significance of miR-15a-5p and CNKSR3 as Novel Prognostic Biomarkers in Non-Small Cell Lung Cancer. Anti-Cancer Agents Med. Chem. 2018, 18, 1695-1701. [CrossRef]

118. Liu, T.; Xu, Z.; Ou, D.; Liu, J.; Zhang, J. The miR-15a/16 gene cluster in human cancer: A systematic review. J. Cell. Physiol. 2019, 234, 5496-5506. [CrossRef]

119. Bozok Çetintaş, V.; Tetik Vardarlı, A.; Düzgün, Z.; Tezcanlı Kaymaz, B.; Açıkgöz, E.; Aktuğ, H.; Kosova Can, B.; Gündüz, C.; Eroğlu, Z. miR-15a enhances the anticancer effects of cisplatin in the resistant non-small cell lung cancer cells. Tumour Biol. 2016, 37, 1739-1751. [CrossRef]

120. Liu, W.; Wang, X.; Liu, Z.; Wang, Y.; Yin, B.; Yu, P.; Duan, X.; Liao, Z.; Chen, Y.; Liu, C.; et al. SGK1 inhibition induces autophagy-dependent apoptosis via the mTOR-Foxo3a pathway. Br. J. Cancer 2017, 117, 1139-1153. [CrossRef]

121. Zhu, R.; Yang, G.; Cao, Z.; Shen, K.; Zheng, L.; Xiao, J.; You, L.; Zhang, T. The prospect of serum and glucocorticoid-inducible kinase 1 (SGK1) in cancer therapy: A rising star. Ther. Adv. Med. Oncol. 2020, 12, 1758835920940946. [CrossRef]

122. Braicu, C.; Gulei, D.; Cojocneanu, R.; Raduly, L.; Jurj, A.; Knutsen, E.; Calin, G.A.; Berindan-Neagoe, I. $\mathrm{miR-181a/b}$ therapy in lung cancer: Reality or myth? Mol. Oncol. 2019, 13, 9-25. [CrossRef] [PubMed]

123. Yang, J.; Liu, H.; Wang, H.; Sun, Y. Down-regulation of microRNA-181b is a potential prognostic marker of non-small cell lung cancer. Pathol. Res. Pract. 2013, 209, 490-494. [CrossRef] [PubMed]

124. Huang, P.; Ye, B.; Yang, Y.; Shi, J.; Zhao, H. MicroRNA-181 functions as a tumor suppressor in non-small cell lung cancer (NSCLC) by targeting Bcl-2. Tumour Biol. 2015, 36, 3381-3387. [CrossRef]

125. Wang, X.; Chen, X.; Meng, Q.; Jing, H.; Lu, H.; Yang, Y.; Cai, L.; Zhao, Y. MiR-181b regulates cisplatin chemosensitivity and metastasis by targeting TGFbetaR1/Smad signaling pathway in NSCLC. Sci. Rep. 2015, 5, 17618. [CrossRef] [PubMed]

126. Liu, K.; Xie, F.; Gao, A.; Zhang, R.; Zhang, L.; Xiao, Z.; Hu, Q.; Huang, W.; Huang, Q.; Lin, B.; et al. SOX2 regulates multiple malignant processes of breast cancer development through the SOX2/miR-181a-5p, miR-30e-5p/TUSC3 axis. Mol. Cancer 2017, 16, 62. [CrossRef] [PubMed]

127. Cao, Y.; Zhao, D.; Li, P.; Wang, L.; Qiao, B.; Qin, X.; Li, L.; Wang, Y. MicroRNA-181a-5p Impedes IL-17-Induced Nonsmall Cell Lung Cancer Proliferation and Migration through Targeting VCAM-1. Cell. Physiol. Biochem. 2017, 42, 346-356. [CrossRef]

128. Jin, X.; Chen, Y.; Chen, H.; Fei, S.; Chen, D.; Cai, X.; Liu, L.; Lin, B.; Su, H.; Zhao, L.; et al. Evaluation of Tumor-Derived Exosomal miRNA as Potential Diagnostic Biomarkers for Early-Stage Non-Small Cell Lung Cancer Using Next-Generation Sequencing. Clin. Cancer Res. 2017, 23, 5311-5319. [CrossRef]

129. Bi, J.; Zeng, X.; Zhao, L.; Wei, Q.; Yu, L.; Wang, X.; Yu, Z.; Cao, Y.; Shan, F.; Wei, M. miR-181a Induces Macrophage Polarized to M2 Phenotype and Promotes M2 Macrophage-mediated Tumor Cell Metastasis by Targeting KLF6 and C/EBPalpha. Mol. Ther. Nucleic Acids 2016, 5, e368. [CrossRef]

130. Xi, X.; Zhang, J.; Wang, J.; Chen, Y.; Zhang, W.; Zhang, X.; Du, J.; Zhu, G. SGK1 Mediates Hypoxic Pulmonary Hypertension through Promoting Macrophage Infiltration and Activation. Anal. Cell. Pathol. 2019, 2019, 3013765. [CrossRef]

131. Zhang, J.; Cao, J.; Ma, S.; Dong, R.; Meng, W.; Ying, M.; Weng, Q.; Chen, Z.; Ma, J.; Fang, Q.; et al. Tumor hypoxia enhances Non-Small Cell Lung Cancer metastasis by selectively promoting macrophage M2 polarization through the activation of ERK signaling. Oncotarget 2014, 5, 9664-9677. [CrossRef]

132. Rusai, K.; Wagner, B.; Roos, M.; Schmaderer, C.; Strobl, M.; Boini, K.M.; Grenz, A.; Kuhl, D.; Heemann, U.; Lang, F.; et al. The serum and glucocorticoid-regulated kinase 1 in hypoxic renal injury. Cell. Physiol. Biochem. 2009, 24, 577-584. [CrossRef] [PubMed] 
133. Matschke, J.; Wiebeck, E.; Hurst, S.; Rudner, J.; Jendrossek, V. Role of SGK1 for fatty acid uptake, cell survival and radioresistance of NCI-H460 lung cancer cells exposed to acute or chronic cycling severe hypoxia. Radiat. Oncol. 2016, 11, 75. [CrossRef] [PubMed]

134. Jiang, L.; Huang, Q.; Zhang, S.; Zhang, Q.; Chang, J.; Qiu, X.; Wang, E. Hsa-miR-125a-3p and hsa-miR-125a-5p are downregulated in non-small cell lung cancer and have inverse effects on invasion and migration of lung cancer cells. BMC Cancer 2010, 10, 318. [CrossRef] [PubMed]

135. Zhong, L.; Sun, S.; Shi, J.; Cao, F.; Han, X.; Chen, Z. MicroRNA-125a-5p plays a role as a tumor suppressor in lung carcinoma cells by directly targeting STAT3. Tumour Biol. 2017, 39. [CrossRef] [PubMed]

136. Naidu, S.; Shi, L.; Magee, P.; Middleton, J.D.; Lagana, A.; Sahoo, S.; Leong, H.S.; Galvin, M.; Frese, K.; Dive, C.; et al. PDGFR-modulated miR-23b cluster and miR-125a-5p suppress lung tumorigenesis by targeting multiple components of KRAS and NF-kB pathways. Sci. Rep. 2017, 7, 15441. [CrossRef] [PubMed]

137. Yang, R.; Huang, H.; Cui, S.; Zhou, Y.; Zhang, T.; Zhou, Y. IFN-gamma promoted exosomes from mesenchymal stem cells to attenuate colitis via miR-125a and miR-125b. Cell Death Dis. 2020, 11, 603. [CrossRef] [PubMed]

138. Cai, T.; Long, J.; Wang, H.; Liu, W.; Zhang, Y. Identification and characterization of miR-96, a potential biomarker of NSCLC, through bioinformatic analysis. Oncol. Rep. 2017, 38, 1213-1223. [CrossRef]

139. Wu, L.; Pu, X.; Wang, Q.; Cao, J.; Xu, F.; Xu, L.I.; Li, K. miR-96 induces cisplatin chemoresistance in non-small cell lung cancer cells by downregulating SAMD9. Oncol. Lett. 2016, 11,945-952. [CrossRef]

140. Fei, X.; Zhang, J.; Zhao, Y.; Sun, M.; Zhao, H.; Li, S. miR-96 promotes invasion and metastasis by targeting GPC3 in non-small cell lung cancer cells. Oncol. Lett. 2018, 15, 9081-9086. [CrossRef]

141. Wang, H.; Ma, Z.; Liu, X.; Zhang, C.; Hu, Y.; Ding, L.; Qi, P.; Wang, J.; Lu, S.; Li, Y. MiR-183-5p is required for non-small cell lung cancer progression by repressing PTEN. Biomed. Pharmacother. 2019, 111, 1103-1111. [CrossRef]

142. Xu, F.; Zhang, H.; Su, Y.; Kong, J.; Yu, H.; Qian, B. Up-regulation of microRNA-183-3p is a potent prognostic marker for lung adenocarcinoma of female non-smokers. Clin. Transl. Oncol. 2014, 16, 980-985. [CrossRef] [PubMed]

143. Zhu, W.; Zhou, K.; Zha, Y.; Chen, D.; He, J.; Ma, H.; Liu, X.; Le, H.; Zhang, Y. Diagnostic Value of Serum miR-182, miR-183, miR-210, and miR-126 Levels in Patients with Early-Stage Non-Small Cell Lung Cancer. PLoS ONE 2016, 11, e0153046. [CrossRef] [PubMed]

144. Hirono, T.; Jingushi, K.; Nagata, T.; Sato, M.; Minami, K.; Aoki, M.; Takeda, A.H.; Umehara, T.; Egawa, H.; Nakatsuji, Y.; et al. MicroRNA-130b functions as an oncomiRNA in non-small cell lung cancer by targeting tissue inhibitor of metalloproteinase-2. Sci. Rep. 2019, 9, 6956. [CrossRef] [PubMed]

145. Li, J.; Dong, J.; Li, S.; Xia, W.; Su, X.; Qin, X.; Chen, Y.; Ding, H.; Li, H.; Huang, A.; et al. An alternative microRNA-mediated post-transcriptional regulation of GADD45A by p53 in human non-small-cell lung cancer cells. Sci. Rep. 2017, 7, 7153. [CrossRef] [PubMed]

146. Tian, J.; Hu, L.; Li, X.; Geng, J.; Dai, M.; Bai, X. MicroRNA-130b promotes lung cancer progression via PPARgamma/VEGF-A/BCL-2-mediated suppression of apoptosis. J. Exp. Clin. Cancer Res. 2016, 35, 105. [CrossRef] [PubMed]

147. Wang, M.; Wang, Y.; Zang, W.; Wang, H.; Chu, H.; Li, P.; Li, M.; Zhang, G.; Zhao, G. Downregulation of microRNA-182 inhibits cell growth and invasion by targeting programmed cell death 4 in human lung adenocarcinoma cells. Tumour Biol. 2014, 35, 39-46. [CrossRef]

148. Chen, G.; Yu, L.; Dong, H.; Liu, Z.; Sun, Y. MiR-182 enhances radioresistance in non-small cell lung cancer cells by regulating FOXO3. Clin. Exp. Pharmacol. Physiol. 2019, 46, 137-143. [CrossRef]

149. Chang, H.; Liu, Y.H.; Wang, L.L.; Wang, J.; Zhao, Z.H.; Qu, J.F.; Wang, S.F. MiR-182 promotes cell proliferation by suppressing FBXW7 and FBXW11 in non-small cell lung cancer. Am. J. Transl. Res. 2018, 10, 1131-1142.

150. Li, Y.; Sun, Y.; Ren, F.; Li, Y.; Liu, M.; Liu, H.; Chen, J. [Methylation Status of miR-182 Promoter in Lung Cancer Cell Lines]. Zhongguo Fei Ai Za Zhi 2015, 18, 260-265. [CrossRef]

151. Wu, D.; Chen, B.; Cui, F.; He, X.; Wang, W.; Wang, M. Hypoxia-induced microRNA-301b regulates apoptosis by targeting Bim in lung cancer. Cell Prolif. 2016, 49, 476-483. [CrossRef]

152. Shi, Y.K.; Zang, Q.L.; Li, G.X.; Huang, Y.; Wang, S.Z. Increased expression of microRNA-301a in nonsmall-cell lung cancer and its clinical significance. J. Cancer Res. Ther. 2016, 12, 693-698. [CrossRef] [PubMed]

153. Hayashita, Y.; Osada, H.; Tatematsu, Y.; Yamada, H.; Yanagisawa, K.; Tomida, S.; Yatabe, Y.; Kawahara, K.; Sekido, Y.; Takahashi, T. A polycistronic microRNA cluster, miR-17-92, is overexpressed in human lung cancers and enhances cell proliferation. Cancer Res. 2005, 65, 9628-9632. [CrossRef] [PubMed] 
154. Zhang, Y.; Zhang, Y.; Yin, Y.; Li, S. Detection of circulating exosomal miR-17-5p serves as a novel non-invasive diagnostic marker for non-small cell lung cancer patients. Pathol. Res. Pract. 2019, 215, 152466. [CrossRef] [PubMed]

155. Xu, T.; Liu, X.; Han, L.; Shen, H.; Liu, L.; Shu, Y. Up-regulation of miR-9 expression as a poor prognostic biomarker in patients with non-small cell lung cancer. Clin. Transl. Oncol. 2014, 16, 469-475. [CrossRef] [PubMed]

156. Han, L.; Wang, W.; Ding, W.; Zhang, L. MiR-9 is involved in TGF-beta1-induced lung cancer cell invasion and adhesion by targeting SOX7. J. Cell Mol. Med. 2017, 21, 2000-2008. [CrossRef] [PubMed]

157. Wang, H.; Wu, Q.; Zhang, Y.; Zhang, H.N.; Wang, Y.B.; Wang, W. TGF-beta1-induced epithelial-mesenchymal transition in lung cancer cells involves upregulation of miR-9 and downregulation of its target, E-cadherin. Cell. Mol. Biol. Lett. 2017, 22, 22. [CrossRef] [PubMed]

158. Chen, X.; Zhu, L.; Ma, Z.; Sun, G.; Luo, X.; Li, M.; Zhai, S.; Li, P.; Wang, X. Oncogenic miR-9 is a target of erlotinib in NSCLCs. Sci. Rep. 2015, 5, 17031. [CrossRef]

159. Yu, X.; Lin, Q.; Qin, X.; Ruan, Z.; Zhou, J.; Lin, Z.; Su, Y.; Jian, Z. Serum and glucocorticoid kinase 1 promoted the growth and migration of non-small cell lung cancer cells. Gene 2016, 576, 339-346. [CrossRef]

160. Abbruzzese, C.; Mattarocci, S.; Pizzuti, L.; Mileo, A.M.; Visca, P.; Antoniani, B.; Alessandrini, G.; Facciolo, F.; Amato, R.; D'Antona, L.; et al. Determination of SGK1 mRNA in non-small cell lung cancer samples underlines high expression in squamous cell carcinomas. J. Exp. Clin. Cancer Res. 2012, 31, 4. [CrossRef]

161. Pan, H.; Lv, W.; Li, Z.; Han, W. SGK1 protein expression is a prognostic factor of lung adenocarcinoma that regulates cell proliferation and survival. Int. J. Clin. Exp. Pathol. 2019, 12, 391-408.

162. Tang, Z.; Shen, Q.; Xie, H.; Zhou, Z.; Shi, G.; Zhang, C.; Mohammed, A.; Wu, Y.; Ni, S.; Zhou, X. Serum and glucocorticoid-regulated kinase 1 (SGK1) is a predictor of poor prognosis in non-small cell lung cancer, and its dynamic pattern following treatment with SGK1 inhibitor and gamma-ray irradiation was elucidated. Oncol. Rep. 2018, 39, 1505-1515. [CrossRef] [PubMed]

163. Pedersen, P.L. Warburg, me and Hexokinase 2: Multiple discoveries of key molecular events underlying one of cancers' most common phenotypes, the "Warburg Effect", i.e., elevated glycolysis in the presence of oxygen. J. Bioenerg. Biomembr. 2007, 39, 211-222. [CrossRef] [PubMed]

164. Fennell, D.A.; Summers, Y.; Cadranel, J.; Benepal, T.; Christoph, D.C.; Lal, R.; Das, M.; Maxwell, F.; Visseren-Grul, C.; Ferry, D. Cisplatin in the modern era: The backbone of first-line chemotherapy for non-small cell lung cancer. Cancer Treat. Rev. 2016, 44, 42-50. [CrossRef] [PubMed]

165. Scott, S.C.; Pennell, N.A. Early Use of Systemic Corticosteroids in Patients with Advanced NSCLC Treated with Nivolumab. J. Thorac. Oncol. 2018, 13, 1771-1775. [CrossRef] [PubMed]

166. Rotow, J.; Bivona, T.G. Understanding and targeting resistance mechanisms in NSCLC. Nat. Rev. Cancer 2017, 17, 637-658. [CrossRef] [PubMed]

167. He, L.; Liu, K.; Wang, X.; Chen, H.; Zhou, J.; Wu, X.; Liu, T.; Yang, Y.; Yang, X.; Cui, D.; et al. NDRG1 disruption alleviates cisplatin/sodium glycididazole-induced DNA damage response and apoptosis in ERCC1-defective lung cancer cells. Int. J. Biochem. Cell Biol. 2018, 100, 54-60. [CrossRef] [PubMed]

168. Bianchi, F.; Nicassio, F.; Di Fiore, P.P. Unbiased vs. biased approaches to the identification of cancer signatures: The case of lung cancer. Cell Cycle 2008, 7, 729-734. [CrossRef]

169. Brunet, A.; Park, J.; Tran, H.; Hu, L.S.; Hemmings, B.A.; Greenberg, M.E. Protein kinase SGK mediates survival signals by phosphorylating the forkhead transcription factor FKHRL1 (FOXO3a). Mol. Cell. Biol. 2001, 21, 952-965. [CrossRef]

170. Feng, Z.; Liu, L.; Zhang, C.; Zheng, T.; Wang, J.; Lin, M.; Zhao, Y.; Wang, X.; Levine, A.J.; Hu, W. Chronic restraint stress attenuates $\mathrm{p} 53$ function and promotes tumorigenesis. Proc. Natl. Acad. Sci. USA 2012, 109, 7013-7018. [CrossRef]

171. Hasna, J.; Hague, F.; Rodat-Despoix, L.; Geerts, D.; Leroy, C.; Tulasne, D.; Ouadid-Ahidouch, H.; Kischel, P. Orai3 calcium channel and resistance to chemotherapy in breast cancer cells: The p53 connection. Cell Death Differ. 2018, 25, 693-707. [CrossRef]

172. Li, J.; Jia, H.; Xie, L.; Wang, X.; Wang, X.; He, H.; Lin, Y.; Hu, L. Association of constitutive nuclear factor-kappaB activation with aggressive aspects and poor prognosis in cervical cancer. Int. J. Gynecol. Cancer 2009, 19, 1421-1426. [CrossRef] [PubMed]

173. Karin, M.; Greten, F.R. NF-kappaB: Linking inflammation and immunity to cancer development and progression. Nat. Rev. Immunol. 2005, 5, 749-759. [CrossRef] 
174. Jin, X.; Wang, Z.; Qiu, L.; Zhang, D.; Guo, Z.; Gao, Z.; Deng, C.; Wang, F.; Wang, S.; Guo, C. Potential biomarkers involving IKK/RelA signal in early stage non-small cell lung cancer. Cancer Sci. 2008, 99, 582-589. [CrossRef] [PubMed]

175. Chen, W.; Wang, X.; Bai, L.; Liang, X.; Zhuang, J.; Lin, Y. Blockage of NF-kappaB by IKKbeta- or RelA-siRNA rather than the NF-kappaB super-suppressor IkappaBalpha mutant potentiates adriamycin-induced cytotoxicity in lung cancer cells. J. Cell. Biochem. 2008, 105, 554-561. [CrossRef] [PubMed]

176. Wang, X.; Ju, W.; Renouard, J.; Aden, J.; Belinsky, S.A.; Lin, Y. 17-allylamino-17-demethoxygeldanamycin synergistically potentiates tumor necrosis factor-induced lung cancer cell death by blocking the nuclear factor-kappaB pathway. Cancer Res. 2006, 66, 1089-1095. [CrossRef] [PubMed]

177. Wang, X.; Chen, W.; Lin, Y. Sensitization of TNF-induced cytotoxicity in lung cancer cells by concurrent suppression of the NF-kappaB and Akt pathways. Biochem. Biophys. Res. Commun. 2007, 355, 807-812. [CrossRef]

178. Nakanishi, C.; Toi, M. Nuclear factor-kappaB inhibitors as sensitizers to anticancer drugs. Nat. Rev. Cancer 2005, 5, 297-309. [CrossRef]

179. Jones, D.R.; Broad, R.M.; Comeau, L.D.; Parsons, S.J.; Mayo, M.W. Inhibition of nuclear factor kappaB chemosensitizes non-small cell lung cancer through cytochrome c release and caspase activation. J. Thorac. Cardiovasc. Surg. 2002, 123, 310-317. [CrossRef]

180. Denlinger, C.E.; Rundall, B.K.; Jones, D.R. Modulation of antiapoptotic cell signaling pathways in non-small cell lung cancer: The role of NF-kappaB. Semin. Thorac. Cardiovasc. Surg. 2004, 16, 28-39. [CrossRef]

181. Shen, H.M.; Tergaonkar, V. NFkappaB signaling in carcinogenesis and as a potential molecular target for cancer therapy. Apoptosis 2009, 14, 348-363. [CrossRef]

182. Tai, D.J.; Su, C.C.; Ma, Y.L.; Lee, E.H. SGK1 phosphorylation of IkappaB Kinase alpha and p300 Up-regulates NF-kappaB activity and increases N-Methyl-D-aspartate receptor NR2A and NR2B expression. J. Biol. Chem. 2009, 284, 4073-4089. [CrossRef] [PubMed]

183. Karin, M. Nuclear factor-kappaB in cancer development and progression. Nature 2006, 441, $431-436$. [CrossRef] [PubMed]

184. Zitvogel, L.; Apetoh, L.; Ghiringhelli, F.; Kroemer, G. Immunological aspects of cancer chemotherapy. Nat. Rev. Immunol. 2008, 8, 59-73. [CrossRef] [PubMed]

185. Nencioni, A.; Grunebach, F.; Patrone, F.; Ballestrero, A.; Brossart, P. Proteasome inhibitors: Antitumor effects and beyond. Leukemia 2007, 21, 30-36. [CrossRef] [PubMed]

186. Aguilera, C.; Hoya-Arias, R.; Haegeman, G.; Espinosa, L.; Bigas, A. Recruitment of IkappaBalpha to the hes1 promoter is associated with transcriptional repression. Proc. Natl. Acad. Sci. USA 2004, 101, 16537-16542. [CrossRef] [PubMed]

187. Chen, W.; Li, Z.; Bai, L.; Lin, Y. NF-kappaB in lung cancer, a carcinogenesis mediator and a prevention and therapy target. Front. Biosci. (Landmark Ed.) 2011, 16, 1172-1185. [CrossRef]

188. Huang, A.H.; Pan, S.H.; Chang, W.H.; Hong, Q.S.; Chen, J.J.; Yu, S.L. PARVA promotes metastasis by modulating ILK signalling pathway in lung adenocarcinoma. PLoS ONE 2015, 10, e0118530. [CrossRef]

189. Liu, L.; Zhu, H.; Liao, Y.; Wu, W.; Liu, L.; Liu, L.; Wu, Y.; Sun, F.; Lin, H.W. Inhibition of Wnt/beta-catenin pathway reverses multi-drug resistance and EMT in Oct4(+)/Nanog(+) NSCLC cells. Biomed. Pharmacother. 2020, 127, 110225. [CrossRef]

190. Rapp, J.; Jaromi, L.; Kvell, K.; Miskei, G.; Pongracz, J.E. WNT signaling-Lung cancer is no exception. Respir. Res. 2017, 18, 167. [CrossRef]

191. Yang, S.; Liu, Y.; Li, M.Y.; Ng, C.S.H.; Yang, S.L.; Wang, S.; Zou, C.; Dong, Y.; Du, J.; Long, X.; et al. FOXP3 promotes tumor growth and metastasis by activating Wnt/beta-catenin signaling pathway and EMT in non-small cell lung cancer. Mol. Cancer 2017, 16, 124. [CrossRef]

192. Gao, Y.; Liu, Z.; Zhang, X.; He, J.; Pan, Y.; Hao, F.; Xie, L.; Li, Q.; Qiu, X.; Wang, E. Inhibition of cytoplasmic GSK-3beta increases cisplatin resistance through activation of Wnt/beta-catenin signaling in A549/DDP cells. Cancer Lett. 2013, 336, 231-239. [CrossRef] [PubMed]

193. Zhang, J.; Liu, J.; Li, H.; Wang, J. beta-Catenin signaling pathway regulates cisplatin resistance in lung adenocarcinoma cells by upregulating Bcl-xl. Mol. Med. Rep. 2016, 13, 2543-2551. [CrossRef] [PubMed]

194. Tran, L.; Theodorescu, D. Determinants of Resistance to Checkpoint Inhibitors. Int. J. Mol. Sci. 2020, $21,1594$. [CrossRef] [PubMed] 
195. Luke, J.J.; Bao, R.; Sweis, R.F.; Spranger, S.; Gajewski, T.F. WNT/ $\beta$-catenin Pathway Activation Correlates with Immune Exclusion across Human Cancers. Clin. Cancer Res. 2019, 25, 3074-3083. [CrossRef]

196. Lang, F.; Shumilina, E. Regulation of ion channels by the serum- and glucocorticoid-inducible kinase SGK1. FASEB J. 2013, 27, 3-12. [CrossRef]

197. Jang, S.H.; Choi, S.Y.; Ryu, P.D.; Lee, S.Y. Anti-proliferative effect of Kv1.3 blockers in A549 human lung adenocarcinoma in vitro and in vivo. Eur. J. Pharmacol. 2011, 651, 26-32. [CrossRef]

198. Wu, Y.; Gao, B.; Xiong, Q.J.; Wang, Y.C.; Huang, D.K.; Wu, W.N. Acid-sensing ion channels contribute to the effect of extracellular acidosis on proliferation and migration of A549 cells. Tumour Biol. 2017, 39, 1010428317705750. [CrossRef]

199. Lee, I.H.; Dinudom, A.; Sanchez-Perez, A.; Kumar, S.; Cook, D.I. Akt mediates the effect of insulin on epithelial sodium channels by inhibiting Nedd4-2. J. Biol. Chem. 2007, 282, 29866-29873. [CrossRef]

200. Zhan, Z.Y.; Zhong, L.X.; Feng, M.; Wang, J.F.; Liu, D.B.; Xiong, J.P. Over-expression of Orai1 mediates cell proliferation and associates with poor prognosis in human non-small cell lung carcinoma. Int. J. Clin. Exp. Pathol. 2015, 8, 5080-5088.

201. Ge, C.; Zeng, B.; Li, R.; Li, Z.; Fu, Q.; Wang, W.; Wang, Z.; Dong, S.; Lai, Z.; Wang, Y.; et al. Knockdown of STIM1 expression inhibits non-small-cell lung cancer cell proliferation in vitro and in nude mouse xenografts. Bioengineered 2019, 10, 425-436. [CrossRef]

202. Li, W.; Zhang, M.; Xu, L.; Lin, D.; Cai, S.; Zou, F. The apoptosis of non-small cell lung cancer induced by cisplatin through modulation of STIM1. Exp. Toxicol. Pathol. 2013, 65, 1073-1081. [CrossRef] [PubMed]

203. Gualdani, R.; de Clippele, M.; Ratbi, I.; Gailly, P.; Tajeddine, N. Store-Operated Calcium Entry Contributes to Cisplatin-Induced Cell Death in Non-Small Cell Lung Carcinoma. Cancers 2019, 11, 430. [CrossRef] [PubMed]

204. He, M.; Liu, S.; Gallolu Kankanamalage, S.; Borromeo, M.D.; Girard, L.; Gazdar, A.F.; Minna, J.D.; Johnson, J.E.; Cobb, M.H. The Epithelial Sodium Channel (alphaENaC) Is a Downstream Therapeutic Target of ASCL1 in Pulmonary Neuroendocrine Tumors. Transl. Oncol. 2018, 11, 292-299. [CrossRef] [PubMed]

205. Chen, R.; Manochakian, R.; James, L.; Azzouqa, A.G.; Shi, H.; Zhang, Y.; Zhao, Y.; Zhou, K.; Lou, Y. Emerging therapeutic agents for advanced non-small cell lung cancer. J. Hematol. Oncol. 2020, 13, 58. [CrossRef]

206. Talarico, C.; Dattilo, V.; D'Antona, L.; Menniti, M.; Bianco, C.; Ortuso, F.; Alcaro, S.; Schenone, S.; Perrotti, N.; Amato, R. SGK1, the New Player in the Game of Resistance: Chemo-Radio Molecular Target and Strategy for Inhibition. Cell. Physiol. Biochem. 2016, 39, 1863-1876. [CrossRef]

207. Cao, F.; Zhang, Z.H.; Wu, P.; Li, L.; Huang, J.M. Preliminary study of apoptotic inhibition and its molecular mechanism of dexamethasone on cisplatin-induced human lung adenocarcinoma cell line SPCA/I. Sichuan Da Хиe Xue Bao Yi Xue Ban 2013, 44, 902-906.

208. Melotte, V.; Qu, X.; Ongenaert, M.; van Criekinge, W.; de Bruine, A.P.; Baldwin, H.S.; van Engeland, M. The $\mathrm{N}$-myc downstream regulated gene (NDRG) family: Diverse functions, multiple applications. FASEB J. 2010, 24, 4153-4166. [CrossRef]

209. Weiler, M.; Blaes, J.; Pusch, S.; Sahm, F.; Czabanka, M.; Luger, S.; Bunse, L.; Solecki, G.; Eichwald, V.; Jugold, M.; et al. mTOR target NDRG1 confers MGMT-dependent resistance to alkylating chemotherapy. Proc. Natl. Acad. Sci. USA 2014, 111, 409-414. [CrossRef]

210. Lazar, V.; Suo, C.; Orear, C.; van den Oord, J.; Balogh, Z.; Guegan, J.; Job, B.; Meurice, G.; Ripoche, H.; Calza, S.; et al. Integrated molecular portrait of non-small cell lung cancers. BMC Med. Genom. 2013, 6, 53. [CrossRef]

211. Fan, C.; Yu, J.; Liu, Y.; Xu, H.; Wang, E. Increased NDRG1 expression is associated with advanced T stages and poor vascularization in non-small cell lung cancer. Pathol. Oncol. Res. POR 2012, 18, 549-556. [CrossRef]

212. Azuma, K.; Kawahara, A.; Hattori, S.; Taira, T.; Tsurutani, J.; Watari, K.; Shibata, T.; Murakami, Y.; Takamori, S.; Ono, M.; et al. NDRG1/Cap43/Drg-1 may predict tumor angiogenesis and poor outcome in patients with lung cancer. J. Thorac. Oncol. 2012, 7, 779-789. [CrossRef] [PubMed]

213. Wen, Q.; Jiao, X.; Kuang, F.; Hou, B.; Zhu, Y.; Guo, W.; Sun, G.; Ba, Y.; Yu, D.; Wang, D.; et al. FoxO3a inhibiting expression of EPS8 to prevent progression of NSCLC: A new negative loop of EGFR signaling. EBioMedicine 2019, 40, 198-209. [CrossRef] [PubMed]

214. Tian, L.; Guo, N.; Zhang, N.; Miao, Z.; Guo, X.; Peng, N.; Zhang, R.; Miao, Y. Association of ZEB1 and FOXO3a protein with invasion/metastasis of non-small cell lung cancer. Int. J. Clin. Exp. Pathol. 2017, 10, 11308-11316. [PubMed] 
215. Mikse, O.R.; Blake, D.C., Jr.; Jones, N.R.; Sun, Y.W.; Amin, S.; Gallagher, C.J.; Lazarus, P.; Weisz, J.; Herzog, C.R. FOXO3 encodes a carcinogen-activated transcription factor frequently deleted in early-stage lung adenocarcinoma. Cancer Res. 2010, 70, 6205-6215. [CrossRef] [PubMed]

216. Reppert, S.; Boross, I.; Koslowski, M.; Tureci, O.; Koch, S.; Lehr, H.A.; Finotto, S. A role for T-bet-mediated tumour immune surveillance in anti-IL-17A treatment of lung cancer. Nat. Commun. 2011, 2, 600. [CrossRef]

217. Hagenbaugh, A.; Sharma, S.; Dubinett, S.M.; Wei, S.H.; Aranda, R.; Cheroutre, H.; Fowell, D.J.; Binder, S.; Tsao, B.; Locksley, R.M.; et al. Altered immune responses in interleukin 10 transgenic mice. J. Exp. Med. 1997, 185, 2101-2110. [CrossRef]

218. Gough, D.J.; Levy, D.E.; Johnstone, R.W.; Clarke, C.J. IFNgamma signaling-does it mean JAK-STAT? Cytokine Growth Factor Rev. 2008, 19, 383-394. [CrossRef]

219. El Hage, F.; Vergnon, I.; Grunenwald, D.; Soria, J.C.; Chouaib, S.; Mami-Chouaib, F. Generation of diverse mutated tumor antigen-specific cytotoxic T lymphocytes in a lung cancer patient with long survival. Oncol. Rep. 2005, 14, 763-769. [CrossRef]

220. Dennis, K.L.; Blatner, N.R.; Gounari, F.; Khazaie, K. Current status of interleukin-10 and regulatory T-cells in cancer. Curr. Opin. Oncol. 2013, 25, 637-645. [CrossRef]

221. Geginat, J.; Larghi, P.; Paroni, M.; Nizzoli, G.; Penatti, A.; Pagani, M.; Gagliani, N.; Meroni, P.; Abrignani, S.; Flavell, R.A. The light and the dark sides of Interleukin-10 in immune-mediated diseases and cancer. Cytokine Growth Factor Rev. 2016, 30, 87-93. [CrossRef]

222. Cherwinski, H.M.; Schumacher, J.H.; Brown, K.D.; Mosmann, T.R. Two types of mouse helper T cell clone. III. Further differences in lymphokine synthesis between Th1 and Th2 clones revealed by RNA hybridization, functionally monospecific bioassays, and monoclonal antibodies. J. Exp. Med. 1987, 166, 1229-1244. [CrossRef] [PubMed]

223. Anthony, R.M.; Rutitzky, L.I.; Urban, J.F., Jr.; Stadecker, M.J.; Gause, W.C. Protective immune mechanisms in helminth infection. Nat. Rev. Immunol. 2007, 7, 975-987. [CrossRef] [PubMed]

224. Neurath, M.F.; Finotto, S. The emerging role of T cell cytokines in non-small cell lung cancer. Cytokine Growth Factor Rev. 2012, 23, 315-322. [CrossRef] [PubMed]

225. Cannarile, L.; Fallarino, F.; Agostini, M.; Cuzzocrea, S.; Mazzon, E.; Vacca, C.; Genovese, T.; Migliorati, G.; Ayroldi, E.; Riccardi, C. Increased GILZ expression in transgenic mice up-regulates Th-2 lymphokines. Blood 2006, 107, 1039-1047. [CrossRef]

226. Duan, M.C.; Han, W.; Jin, P.W.; Wei, Y.P.; Wei, Q.; Zhang, L.M.; Li, J.C. Disturbed Th17/Treg Balance in Patients with Non-small Cell Lung Cancer. Inflammation 2015, 38, 2156-2165. [CrossRef]

227. Ganesan, A.P.; Johansson, M.; Ruffell, B.; Yagui-Beltran, A.; Lau, J.; Jablons, D.M.; Coussens, L.M. Tumor-infiltrating regulatory $\mathrm{T}$ cells inhibit endogenous cytotoxic $\mathrm{T}$ cell responses to lung adenocarcinoma. J. Immunol. 2013, 191, 2009-2017. [CrossRef]

228. Li, Y.; Cao, Z.Y.; Sun, B.; Wang, G.Y.; Fu, Z.; Liu, Y.M.; Kong, Q.F.; Wang, J.H.; Zhang, Y.; Xu, X.Y.; et al. Effects of IL-17A on the occurrence of lung adenocarcinoma. Cancer Biol. Ther. 2011, 12, 610-616. [CrossRef]

229. Wu, C.; Yosef, N.; Thalhamer, T.; Zhu, C.; Xiao, S.; Kishi, Y.; Regev, A.; Kuchroo, V.K. Induction of pathogenic TH17 cells by inducible salt-sensing kinase SGK1. Nature 2013, 496, 513-517. [CrossRef]

230. Aggarwal, S.; Ghilardi, N.; Xie, M.H.; de Sauvage, F.J.; Gurney, A.L. Interleukin-23 promotes a distinct CD4 T cell activation state characterized by the production of interleukin-17. J. Biol. Chem. 2003, 278, 1910-1914. [CrossRef]

231. Wu, C.; Chen, Z.; Xiao, S.; Thalhamer, T.; Madi, A.; Han, T.; Kuchroo, V. SGK1 Governs the Reciprocal Development of Th17 and Regulatory T Cells. Cell Rep. 2018, 22, 653-665. [CrossRef]

232. Eisenstein, E.M.; Williams, C.B. The T(reg)/Th17 cell balance: A new paradigm for autoimmunity. Pediatr. Res. 2009, 65, 26R-31R. [CrossRef] [PubMed]

233. Marshall, E.A.; Ng, K.W.; Kung, S.H.; Conway, E.M.; Martinez, V.D.; Halvorsen, E.C.; Rowbotham, D.A.; Vucic, E.A.; Plumb, A.W.; Becker-Santos, D.D.; et al. Emerging roles of T helper 17 and regulatory T cells in lung cancer progression and metastasis. Mol. Cancer 2016, 15, 67. [CrossRef] [PubMed]

234. Knochelmann, H.M.; Dwyer, C.J.; Bailey, S.R.; Amaya, S.M.; Elston, D.M.; Mazza-McCrann, J.M.; Paulos, C.M. When worlds collide: Th17 and Treg cells in cancer and autoimmunity. Cell. Mol. Immunol. 2018, 15, 458-469. [CrossRef] [PubMed]

235. Duan, M.C.; Zhong, X.N.; Liu, G.N.; Wei, J.R. The Treg/Th17 paradigm in lung cancer. J. Immunol. Res. 2014, 2014, 730380. [CrossRef] 
236. Sherk, A.B.; Frigo, D.E.; Schnackenberg, C.G.; Bray, J.D.; Laping, N.J.; Trizna, W.; Hammond, M.; Patterson, J.R.; Thompson, S.K.; Kazmin, D.; et al. Development of a small-molecule serum- and glucocorticoid-regulated kinase-1 antagonist and its evaluation as a prostate cancer therapeutic. Cancer Res. 2008, 68, 7475-7483. [CrossRef]

237. Zapf, J.; Meyer, T.; Wade, W.; Lingardo, L.; Batova, A.; Alton, G.; Pallai, P. Drug-like inhibitors of SGK1: Discovery and optimization of low molecular weight fragment leads. In Proceedings of the AACR 107th Annual Meeting 2016, New Orleans, LA, USA, 16-20 April 2016.

238. Mansley, M.K.; Wilson, S.M. Effects of nominally selective inhibitors of the kinases PI3K, SGK1 and PKB on the insulin-dependent control of epithelial Na+ absorption. Br. J. Pharmacol. 2010, 161, 571-588. [CrossRef]

239. Ackermann, T.F.; Boini, K.M.; Beier, N.; Scholz, W.; Fuchss, T.; Lang, F. EMD638683, a novel SGK inhibitor with antihypertensive potency. Cell. Physiol. Biochem. 2011, 28, 137-146. [CrossRef]

240. Ortuso, F.; Amato, R.; Artese, A.; D’Antona, L.; Costa, G.; Talarico, C.; Gigliotti, F.; Bianco, C.; Trapasso, F.; Schenone, S.; et al. In silico identification and biological evaluation of novel selective serum/glucocorticoid-inducible kinase 1 inhibitors based on the pyrazolo-pyrimidine scaffold. J. Chem. Inf. Model. 2014, 54, 1828-1832. [CrossRef]

241. Halland, N.; Schmidt, F.; Weiss, T.; Saas, J.; Li, Z.; Czech, J.; Dreyer, M.; Hofmeister, A.; Mertsch, K.; Dietz, U.; et al. Discovery of N-[4-(1H-Pyrazolo[3,4-b]pyrazin-6-yl)-phenyl]-sulfonamides as Highly Active and Selective SGK1 Inhibitors. ACS Med. Chem. Lett. 2015, 6, 73-78. [CrossRef]

242. Toska, E.; Castel, P.; Chhangawala, S.; Arruabarrena-Aristorena, A.; Chan, C.; Hristidis, V.C.; Cocco, E.; Sallaku, M.; Xu, G.; Park, J.; et al. PI3K Inhibition Activates SGK1 via a Feedback Loop to Promote Chromatin-Based Regulation of ER-Dependent Gene Expression. Cell Rep. 2019, 27, 294-306.e295. [CrossRef]

243. Liang, X.; Lan, C.; Zhou, J.; Fu, W.; Long, X.; An, Y.; Jiao, G.; Wang, K.; Li, Y.; Xu, J.; et al. Development of a new analog of SGK1 inhibitor and its evaluation as a therapeutic molecule of colorectal cancer. J. Cancer 2017, 8, 2256-2262. [CrossRef] [PubMed]

244. Bezzerides, V.J.; Zhang, A.; Xiao, L.; Simonson, B.; Khedkar, S.A.; Baba, S.; Ottaviano, F.; Lynch, S.; Hessler, K.; Rigby, A.C.; et al. Inhibition of serum and glucocorticoid regulated kinase-1 as novel therapy for cardiac arrhythmia disorders. Sci. Rep. 2017, 7, 346. [CrossRef] [PubMed]

Publisher's Note: MDPI stays neutral with regard to jurisdictional claims in published maps and institutional affiliations.

(C) 2020 by the authors. Licensee MDPI, Basel, Switzerland. This article is an open access article distributed under the terms and conditions of the Creative Commons Attribution (CC BY) license (http://creativecommons.org/licenses/by/4.0/). 